\title{
Buffer Zone Trade in Northeast Asia in the Second Century B.C.
}

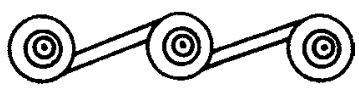

\author{
SUN-MI PARK
}

\section{INTRODUCTION}

IN ANY GIVEN SOCIETY, trade is not only a method of acquiring goods that are not available locally, but also a way of interacting in political economic terms with other societies. Many researchers have shown that trade played a key role in the formation of complex societies, particularly states (Bandy 2005; Bintliff 1997; Ch'oe 1983; Cosmo 1994; Hodder 1982; Mikami 1966; Polanyi 1957; Renfrew 1975). Less attention has been paid to the dynamics of trade, particularly in the complex, multiethnic trade landscapes of East Asia in the late first millennium B.C. and early first millennium A.D. Little is known about the specific roles of different actors in conducting trade and their impact on local political economies. This article helps rectify these gaps by examining the Wiman Chosonn polity, an early state in ancient Korea, 195-108 B.C. This polity is considered to have developed through external trade contacts (Ch'oe 1985; Park 2009).

The Wiman Chosŏn trade system has attracted special attention from archaeologists and historians because coins from Han China, with which it shared a border, have been discovered within its territory. In the 1980s, Ch'oe (1985) convincingly demonstrated that the knife-shaped bronze coins in circulation at Wiman Choson sites were the main currency of the late period of the Yan 燕 polity (one of the Eastern Zhou period states of China). This is strong archaeological evidence that Wiman Chosŏn conducted significant trade with polities in central China. Sŏ (1988) interpreted historical documents to suggest that the money was brought to Old Chosón by Wiman, a local Yan leader. When the Yan king, Lu Wan, rebelled against the Han and escaped to Xiungnu, Wiman also fled there with his people. A few years later, archaeologist Pak (1993:55) argued that the knife-shaped coins could be connected to Wiman's followers who migrated east of the Liao River. In the 2000s, as archaeology in Korea advanced and archaeological records in China and North Korea became more accessible, this author examined the currencies discovered in Manchuria and the Korean Peninsula (Park 2000, 2005, 2007). My findings supported arguments by other ar-

Sun-Mi Park is a Research Fellow at the Archaeology Laboratory, University of Seoul, Department of Korean History. 
chaeologists that some of the sites with currencies are related to the Old Choson and Wiman Chosŏn polities (Ch'oe 1985; Son 1990; Tamura 1994; Yi 2002; Zhang 2004). ${ }^{1}$ As these archaeologists of China, Japan, and Korea have observed, even though currencies used by polities in the central plains of China circulated in southwestern Manchuria and the northwestern part of the Korean Peninsula, the archaeological records of these regions are obviously distinct from those of the central plains.

Comparing the structure of the Wiman Choson trade system with that of Old Chosŏn, Ch'oe (1985) argues that Wiman Chosŏn took advantage of its location interposed between Han and neighboring polities to control trade between the Han and those peripheral polities and generate some trade surplus for itself. Ch'oe thus argues that Wiman Choson practiced a form of "central place trade" as described by Lamberg-Karlovsky (1972). He distinguishes three different processes of long-distance trade: Direct Contact Trade, Exchange or Indirect Contact Trade, and Central Place Trade. In the strictest sense, central place trade is evident when goods are produced or resources are present at a few central points. Thus site $\mathrm{C}$, a central point, may be located beyond the spheres of influence of sites A and B but control the resources or means of production desired by sites A and B. Acting as a central place, site C may either transship materials produced in other centers or export its own materials or resources. Alternatively, the resources or transshipment of goods may be under the control of people originating from either site A or B who reside as foreigners at site C. In this respect, there may be direct contact between the central place (site C) and either A or B or both. In this theory, the central place, C, must represent a different culture than either A or B. The archaeologist must therefore attempt to determine whether people from sites A or B are physically present at site C (i.e., as a trading colony within the central place) or whether material remains of $\mathrm{A}$ or $\mathrm{B}$ are present at $\mathrm{C}$ as a result of trade (Lamberg-Karlovsky 1972:222).

It is argued here that Lamberg-Karlovsky's theory of Central Place Trade does not adequately explain the trade conducted in Wiman Choson. First, it is not clear that Wiman Chosŏn presents the conditions described above for a central place. Further, it is doubtful whether Wiman Chosŏn acted as a central place with respect to Han. Archaeological records and historical documents such as the Shiji 史記 and Sanguozhi 三國志 show that Han was a fully developed state that functioned as a political and economic center (called a "core" here), while Wiman Chosŏn was a semi-core polity geographically adjacent to Han. ${ }^{2}$ In applying Lamberg-Karlovsky's theory, Ch'oe (1985) oversimplified the nature of trade in Northeast Asia and neglected to conduct a thorough analysis of the archaeological data.

As we will see in the following sections, archaeological research conducted thus far indicates that the three states trading with each other during the Wiman Choson period each had different economies: Han had developed a monetary system, Wiman Chosŏn used an imported currency, and Chin had a non-monetary economy. During the Wiman Choson period, the majority of trade items were geographically concentrated in the Pyongyang region of the northwestern part of the Korean Peninsula; only a limited number appear in the central and southern parts of the peninsula. Coins began to appear in the central and southern parts of the peninsula only from the first century B.C. ${ }^{3}$ How can such discrepancies in the distribution of trade items among the three states be explained?

A theory for understanding the Wiman Chosonn trade system must account for these archaeological findings. The problem should be approached from the perspec- 
tives of all three parties concerned in trade. I have therefore surveyed the items featured in trade between Han, Wiman Chosŏn, and Chin and compared and analyzed the contexts for imported and exported goods moving through Wiman Choson in this three-way trade. The target sites for this analysis are located on the Korean Peninsula and date to periods before and after the fall of Wiman Chosŏn. I also utilize data preserved in historical records to analyze trade items that have left no trace in the material record. I account for certain archaeological changes appearing in the Korean Peninsula from the second to first centuries B.C. as the result of the limited transmission of Han Chinese materials by Wiman Chosŏn (functioning as a semi-core) to the surrounding regions. Finally, I argue that Wiman Choson was more a "buffer zone" than a "central place" in its trade relationships with Han and Chin.

\section{THE THEORY OF BUFFER ZONE TRADE}

Buffer Zone Trade is a type of exchange between a fully developed state (C), a less developed state $(\mathrm{B})$, and a complex society $(\mathrm{P})$ at the geographical periphery to $\mathrm{C}$ (Fig. 1). C may be a centralized state with a well-organized monetary economy; B may be located between $\mathrm{C}$ and $\mathrm{P}$; and $\mathrm{P}$ may be only one polity or several polities peripheral to C. According to this model, $\mathrm{P}$ at the periphery acquires C's advanced products through B's mediation. B trades with $\mathrm{C}$, then provides neighboring polities with C's products. B thereby regulates and at times restricts the flow of C's products to the periphery. B thus acts as a filter on C's cultural influences, softening the impact of C's culture on peripheral societies and preventing peripheral polities from losing their indigenous cultures entirely or collapsing. On the other hand, because there is no such intermediary between $\mathrm{C}$ and $\mathrm{B}, \mathrm{B}$ experiences the direct impact of C's culture, as reflected in material remains. The reverse is also true: B's culture ultimately influences and becomes part of C's culture as well. This is because trade of any type, regardless of scale or whether exchange is direct or indirect, can be accompanied by nonmaterial elements of culture, including ideologies, symbols and value systems, political, social, and religious concepts, and art. In particular, kinship relationships, social stratification, and social definitions of gender frequently change during periods of prolonged contact with another culture.

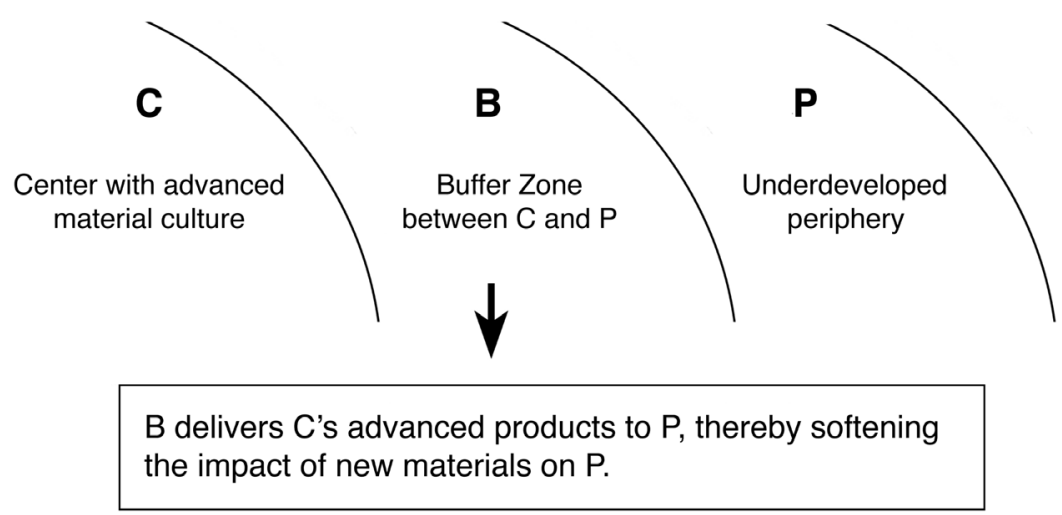

Fig. 1. Schematic diagram of the Buffer Zone Trade model. 
Currencies issued by Yan and Han flowed into the Taedong River basin (centered on modern Pyongyang), yet there was no influx of these currencies to the southern part of the Korean Peninsula during the Wiman Chosŏn era. Only after Wiman Chosŏn collapsed in the first century B.C. were coins introduced to this region, along with a flourishing trade in Han goods. In addition, Chin was replaced as the representative polity of the southern part of the Korean Peninsula by the polities known historically as the Three Han (三韓): Mahan (馬韓), Pyŏnhan (弁韓), and Chinhan (辰 韓). ${ }^{4}$ The archaeological and historical data have three implications: (1) Wiman Chosŏn was directly or indirectly involved in both Han and Chin trade groups; (2) trade groups using monetary currencies were acting in the Taedong River basin; and (3) the collapse of Wiman Choson was a turning point for trade between Han and polities in the southern part of the Korean Peninsula.

Although the location of the boundary between Wiman Chosŏn and Han is still a matter of debate, archaeological records of northeastern China and the Korean Peninsula indicate that Wiman Chosón could have exerted an influence on the region to the east of the Liao River from its capital at modern-day Pyongyang. The archaeological data of the region east of the Liao River reflects a mixture of indigenous cultures, the Warring States culture of the central plains of the Yellow River valley, and the nomadic cultures of the northern part of China. Based on statements in the Shiji and Sanguozhi, it may be surmised that this region was occupied by migrants from Yan, Qi, and Zhao. ${ }^{5}$ The Shiji states that Wiman was a refugee from the state of Yan. ${ }^{6}$ I believe that Yan refugees settled among local people in the western border of Old Chosŏn. According to the historical documents, a few thousand migrants from the central plains fled to Old Chosón, where its king allowed them to settle in the western region of his territory. Other refugees from Qi and Zhao were probably also allowed to settle on the western border of Old Chosonn.

Wiman Chosŏn was a kind of alliance state, governed by a combination of local elite groups and migrant elite groups. Several named individuals held Han Chinesestyle official titles such as Sang 相, Kyŏng 卿, and Changgun 將軍 in the government of Wiman Chosŏn. Others had titles such as Piwang 裨王 and Taesin 大臣 that appear to reflect a local system. ${ }^{7}$ In addition, the name of the person in each public post reveals aspects of relationships with both the indigenous people and the Han people (Kim 1994; No 1998). Wiman Choson possessed the weaponry to attack and take over neighboring polities, some of which surrendered of their own accord. Wiman Chosón thus expanded trade and its territory by a few thousand $l i$ 里 in every direction. ${ }^{8}$

Written records related to the war between Wiman Chosŏn and Han provide clues about the geography of trade and support evidence from the archaeological record concerning the trade routes connecting Pyongyang to the Han capital at Chang'an. The historical sources mention both land and marine routes to Pyongyang from the central plains of China. A land route ran northeast through Hebei Province, across the Liao River, and then southeast to the capital of Wiman Choson known as the Wanggŏm fortress. There were also two marine routes-one led directly from Shandong across the gulf to the mouth of the Lie (modern Taedong) River, while the other followed the coast along the Gulf of Bohai to the mouth of the Lie River and the Wanggom fortress. Given these accounts, it is likely that the Wiman Choson territory comprised a major transportation point connecting the southern part of the Korean Peninsula to the central plains of China. If we include neighboring polities such as Chinborn and 
Imdun, which were subordinate to Wiman Chosŏn, Wiman Chosŏn's influence extended to the Russian Maritime Province in the northeast and through the southern part of the Korean Peninsula connecting to the Japanese archipelago.

At that time, Han China possessed a highly developed material culture. Its commercial specialists (i.e., entrepreneurs, merchants, and traders) were key actors in the Han economy and used coins as the medium of exchange (Zhang 2003). Using the overland route, Han goods could reach the southern part of the Korean Peninsula only after moving through the northwestern part. Materials were also able to flow to the southern part of Korea along the coast of the northwest Korean Peninsula via a sea route, with islands linking the Liaodong Peninsula and the Shandong Peninsula. Polities in the Japanese archipelago could have used a marine route to the east shore of China, but as yet we have no evidence that navigation techniques were sufficiently sophisticated to permit direct passage. The safest and most technologically feasible way to get to the Japanese archipelago from China was to use the islands along the Korean Peninsula as way stations in the journey.

Considering these geographical parameters, it is likely that Wiman Chosŏn's location led it to play a key role in moving technologically sophisticated Han materials into the southern peninsula and the archipelago. According to written texts a formal agreement between Wiman Chosonn and Han stipulated that Han would offer property, most notably iron weapons and prestige goods, in return for Wiman agreeing to allow neighboring chiefs in the periphery to pay tribute to the Han emperor. ${ }^{9}$ In the late second century B.C., however, Wiman Chosŏn's King Ugŏ (Wiman's grandson) broke the agreement by blocking neighboring chiefs from visiting Han. From the Han perspective, Wiman Chosŏn was just a neighboring state at its periphery, but for polities in the periphery of China (including the southern peninsula and the archipelago), Wiman Chosonn came to represent a semi-core state, manipulating the flow of advanced materials southward. After the collapse of Wiman Chosŏn, many more Han goods were transported into these peripheral societies, suggesting that a new trade system was established between Han and the polities in the southern part of the peninsula (Park 2008, 2009).

The fact that Wiman Choson acted as a semi-core in both the political and geographical senses may have allowed it to exert monopolistic power over trade between polities. Wiman established ascendancy over all the polities in its periphery. It alone could act as a semi-core capable of engaging in regular commercial transactions with Han.

Taking an economic rather than political perspective, I propose the concept of Buffer Zone Trade as a model for understanding the attributes of Wiman Chosón trade relations with Han and Chin. Han fostered a monetary and market economy that included specialized merchants engaging in commercial transactions of many kinds. In the absence of its own monetary system, Wiman Chosŏn used Han currencies such as Banliang and Wuzhu coins. Wiman Choson's neighboring polities such as the Chin did not accept or acquire any foreign coins.

Research on Roman period Europe seems to suggest that similar circumstances existed in the trade between Rome and Free Germany (Hedeager 1988; Scheidel 2008). Three polities were involved: the Roman Empire, characterized by an advanced monetary and market economy; a loose confederacy of Celts, who maintained a limited money economy (though perhaps lacking an independent coinage system) including markets and merchant classes; and Free Germany, composed of Germanic 
peoples using money without a monetary economy, perhaps with moneyless markets. Hedeager (1988) suggests there was a buffer zone between Rome and Germany, but neglects the social underpinnings of exchange. It was simply a geographical area between Rome and Germany that existed in political vacuum, lacking a unified state through which goods flowed. The notion of a geographic buffer zone without consideration for the political dynamics (i.e., the political motivation to create asymmetries in the control of resource flows) and the social and cultural consequences of contact is different from the Buffer Zone Trade theory employed here. As demonstrated below, in the Buffer Zone Trade model, a semi-core polity both buffers the flow of materials and softens the impact of those materials on an external, peripheral culture. Wiman Chosŏn's external trade relations are better explained by this more robust model of material and cultural flows between differently scaled polities in a complex landscape. I provide an overview of the material evidence for these exchange relationships in the next section.

OBJECTS OF TRADE

Imports to Wiman Chosǒn from Han

Coins-Coins, including both Banliang and Wuzhu varieties, were the main items traded from Han to Wiman Chosŏn. Their distribution can be seen in Figure 2. When Han reunified the polities of the central plains, it adopted Qin's currency system and issued Banliang coins. The Banliang coin is a round coin with a square hole in the center; it features the characters ban (半) and liang (兩) to the right and left of the center respectively (Fig. 2:7). Liang was a unit of weight equivalent to $15.6 \mathrm{~g}$; ban means half. A Banliang coin therefore represented half of one liang, or $7.8 \mathrm{~g}$. Some Banliang coins from early Han are similar to those from the Qin Empire, but Banliang coins were issued several times in early Han and there are also examples of Han coins very different from those found in the Qin Empire. These are the lightest and smallest of three types; the characters on these Banliang coins were the longest and most uniform in length compared to other similar coins.

In 118 B.C., Han imposed a new currency policy and started minting a new type of coin known as the Wuzhu coin (Fig. 2:8), a round coin with a square hole in the center and the characters $w u$ (五) on the right and $z h u$ (銖) on the left. $W u$ means five and $z h u$ was a unit of weight. One $z h u$ was $0.65 \mathrm{~g}$; five $z h u$ was $3.25 \mathrm{~g}$. Han Wuzhu coins can be divided into two categories: those from Western Han and those from Eastern Han. Some Wuzhu coins have distinctive shapes marking the front, such as a bar, triangle, square, or star. Some Wuzhu coins have symbols on the back as well, such as four diagonals extending from the corners of the square. The coins can be dated by the shape of the characters on them and their molds.

The distribution map in Figure 2 is based on a statistical study of the materials by Park (2009). It reveals a widespread use of these central plains coins in Manchuria and the northwestern part of the Korean Peninsula in the third to second centuries B.C. From an early period, payments were made in coins to these regions on a large scale.

Figure 2 also shows that the distribution of the two types of Han-period coins (Banliang and Wuzhu) is different from coins minted during the Warring States period, including shovel-shaped coins (Fig. 2:1,2), round coins (Fig. 2:3, 4), and knifeshaped coins (Fig. 2:5,6) from Yan. Warring States period coins are distributed widely 


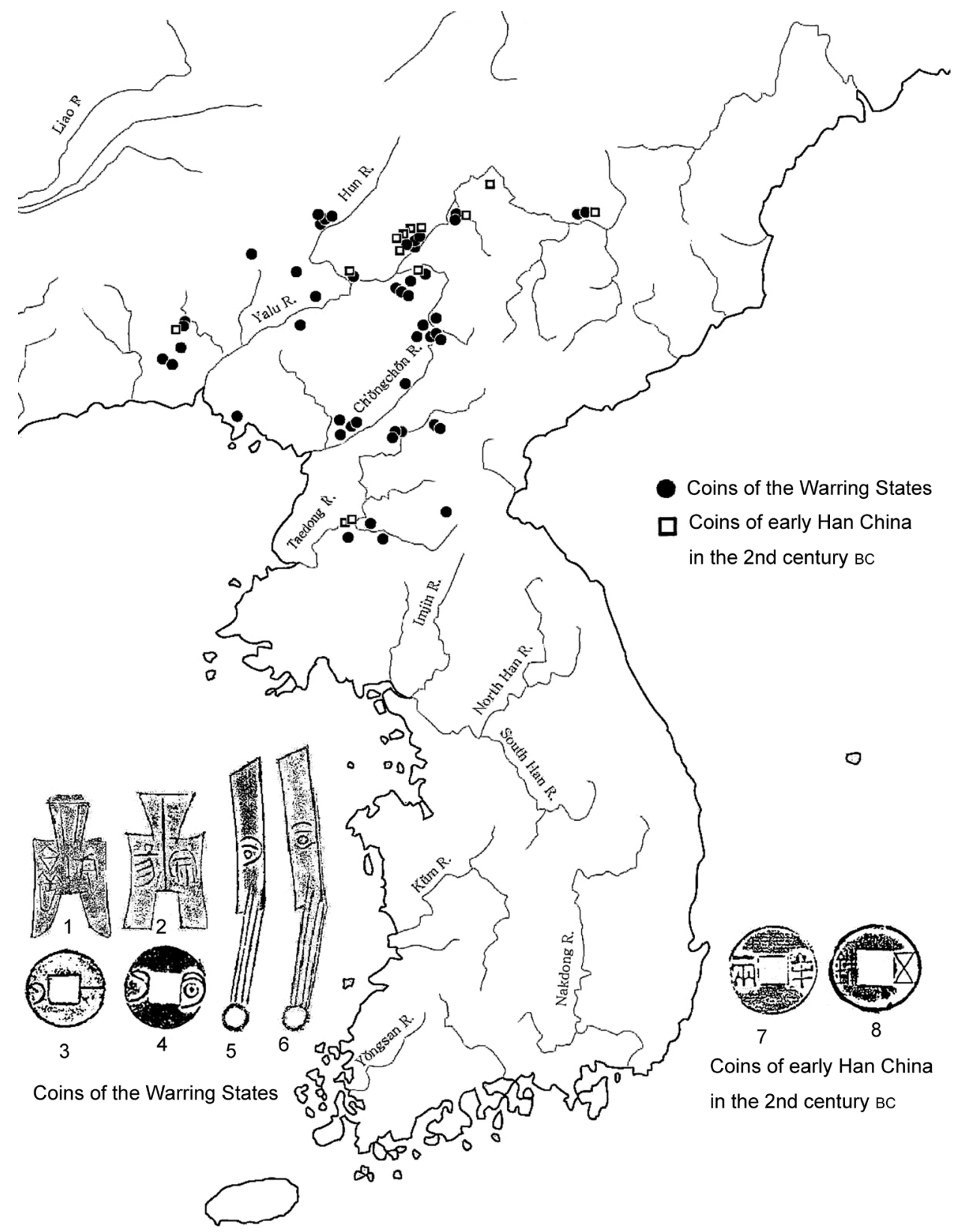

Fig. 2. The distribution of coins on the Korean Peninsula in the third to second centuries B.C. 1, 2: shovel-shaped coins; 3, 4: round coins of Yan; 5, 6: knife-shaped coins; 7, 8: coins of early Han.

in south Manchuria and the northwestern part of the peninsula and have been discovered in various features, such as tombs, settlement sites, palace sites, and even hoards. In contrast, Han-period coins have a limited distribution in the Pyongyang and Chagang provinces, and the number of sites where Han coins are found is fewer than sites 
with Warring State coins, implying that these Banliang and Wuzhu coins were not deeply imbedded in the local economy.

Interestingly, as the map shows, there was no coinage used in the southern part of the Korean Peninsula. As mentioned earlier, coins started flowing to this area only after the collapse of Wiman Chosŏn. The distribution of coins before and after the Wiman Chosŏn era suggests that Wiman Chosŏn did not use coins for domestic transactions or for trade with Chin in the southern part of the Korean Peninsula. This will be discussed in more detail below.

Another point worthy of attention is that molds for the Banliang coins have been discovered in the Pyongyang area. Seven recovered pieces were manufactured during the reigns of emperors Wen 文 (180-157 в.с.) and Wu 武 (141-87 в.с.) in the early Han period (Park 2008). According to Wang (2008), molds for Wuzhu and Daquan wushi 大泉五十 coins were discovered at the Lelang site in the Pyongyang region. According to historical and archaeological evidence, this region was probably a large walled settlement at the center of the Wiman Choson polity. Even though these molds were discovered in Pyongyang, it does not seem that coins were manufactured there because the molds are found in such small quantities. Moreover, coins made from these molds have not been found in the Pyongyang region. It is nevertheless possible that the coins were redistributed from Pyongyang.

Iron Products-Other than coins, the most common objects imported from Han are iron goods, particularly swords and axes. Based on data from the Sejung-ni and Yongyŏn-dong sites dating to the third century B.C., iron products such as semi-lunarshaped knives and spears were produced locally during the earlier period of Old Chosŏn. Iron goods were significantly more common at Wiman Chosŏn era sites and they were largely imported. Swords, daggers, axes, chisels, crossbows, and other iron products were transported to Wiman Chosonn. Findings at the Chŏngbaek-tong and T'osŏng-dong tombs in Pyongyang, Karhyŏn-ni and Songsan-ni in Hwanghae Province, and Hogok-dong and Odong in Hamgyŏng Province are all representative of this iron trade. It is interesting to note that weaponry (particularly swords and axes) has been discovered in most of the sites that include tools for woodworking (Fig. 3). Weaponry was not as common in the southern part of the Korean Peninsula, where Chin was presumably located, during the Wiman Choson era, a fact that is important for understanding the landscape of exchange in this region (Fig. 4). This will be addressed in more detail below.

Significantly, iron goods such as the axe and the hoe are in the classic Warring States or Han style; they are accompanied by indigenous products such as halberds and locally made pottery (Yi 2005). Moreover, slender bronze daggers representative of the material culture of Wiman Chosŏn are discovered in situ at each site, suggesting that the people importing iron goods might not have been foreign to the region but rather local indigenous elites (Table 1).

Iron products were transported to Hamgyŏng Province, located far to the east of the center of Wiman Choson. The iron tools found in the region are mostly iron tools such as axes, hatchets, and hand knives. They indicate that this region already had access to iron material in the second century B.C.

Bronze Products - Han-style mirrors, vessels, and harnesses for horses and carriages were imported in small quantities to Wiman Chosŏn (Fig. 5). These bronze items have been discovered at Chŏngbaek-tong and T'osŏng-dong in Pyongyang, Pudŏng-ni 
Number in each item

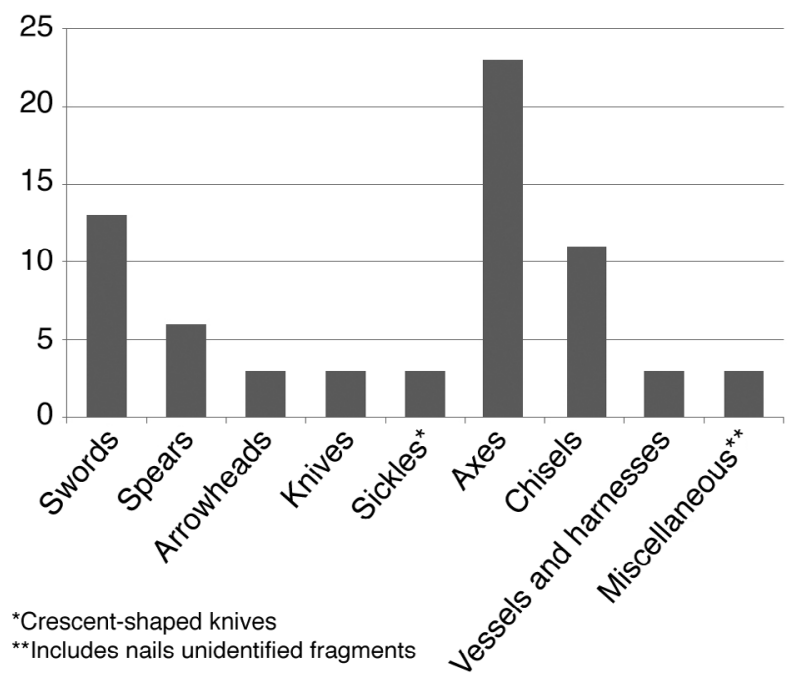

Fig. 3. Types of Han-produced iron products imported to Wiman Chosŏn.

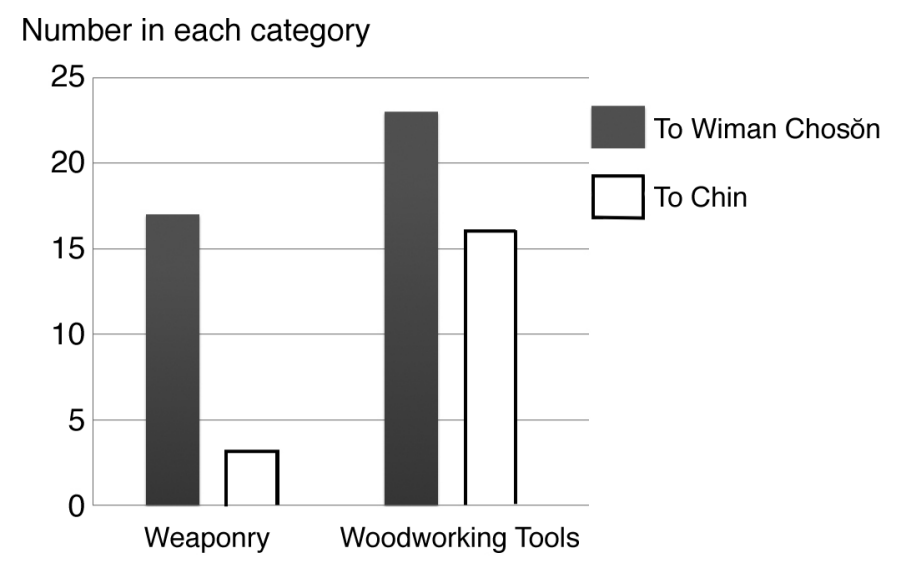

Fig. 4. Comparison of Han-produced iron products imported to Wiman Chosŏn and Chin.

and Sŏksan-ni in Hwanghae Province, and Rihwa-dong and Hasedong-ri in Hamgyŏng city. Fittings for horses and carriages, such as the frames and the caps of parasols, figure prominently among the imports. Vessels such as jars with covers have been recovered from indigenous-style, wooden chamber tombs in Pyongyang.

There are two specimens of early Han Chinese mirrors unearthed from T'osŏngdong tomb 486 in Pyongyang. One of them has a diameter of $9.0 \mathrm{~cm}$ with a knob on the plain back. The other has a diameter of $15.9 \mathrm{~cm}$ with a knob placed in the center of a patterned back, which has a frame on the perimeter and two circles near the frame, as well as three figures of dragons on a zigzag pattern arranged in a regular triangle. Although nine specimens of Han mirrors were discovered within the Lelang earthen wall, these mirrors all date to the first century B.C., which means that significant import of mirrors did not begin until after the collapse of Wiman Chosŏn. 


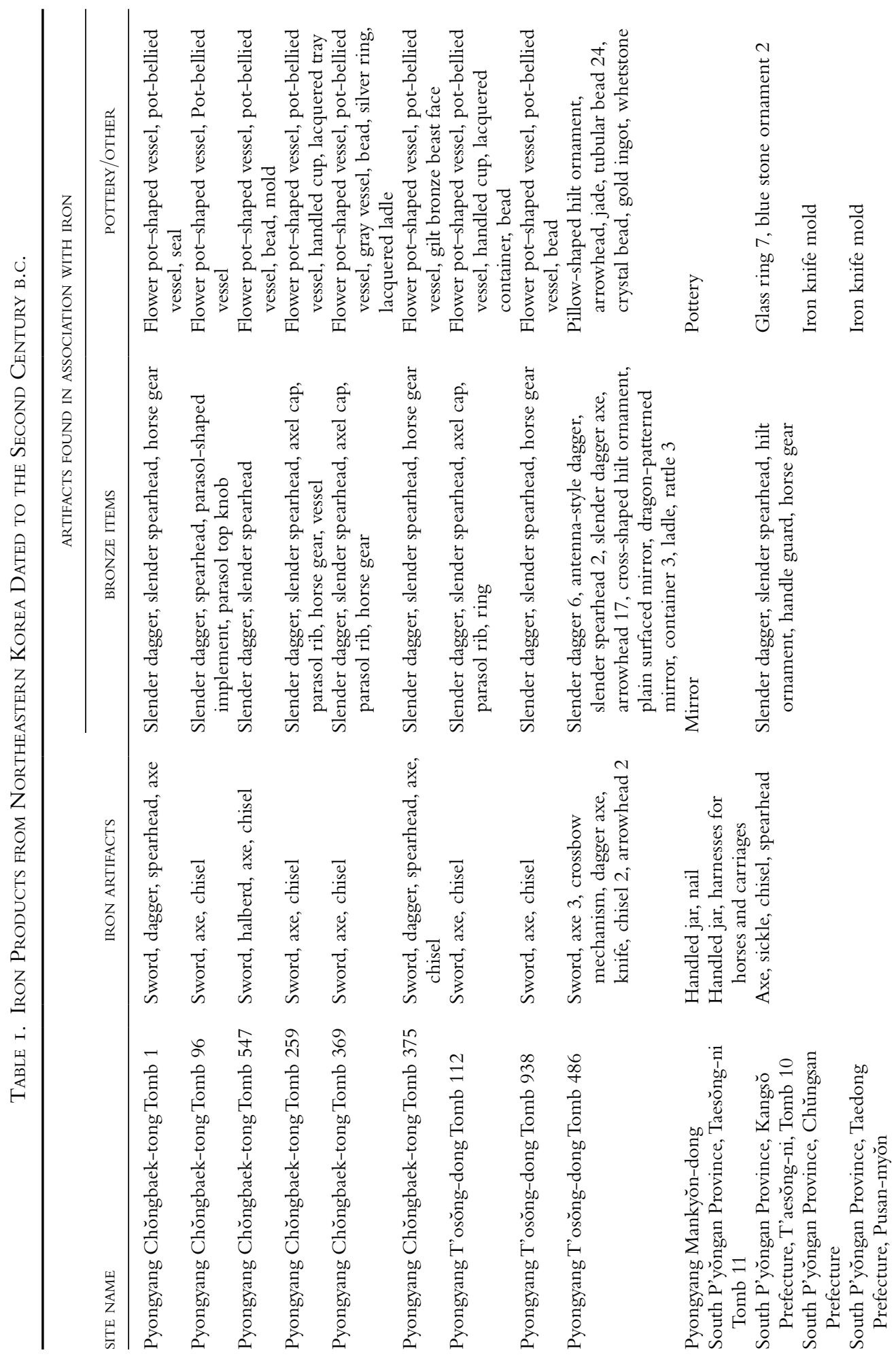



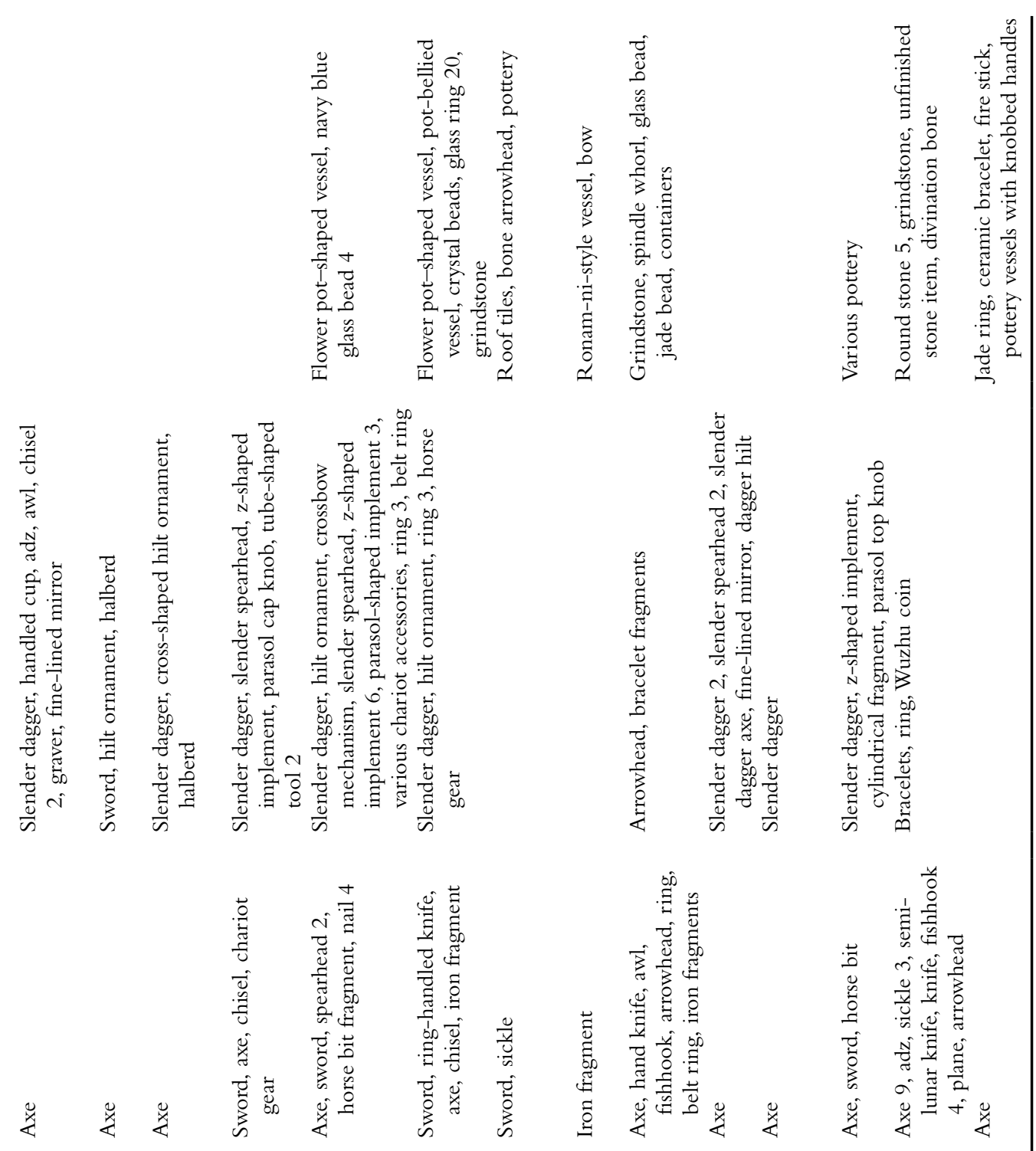

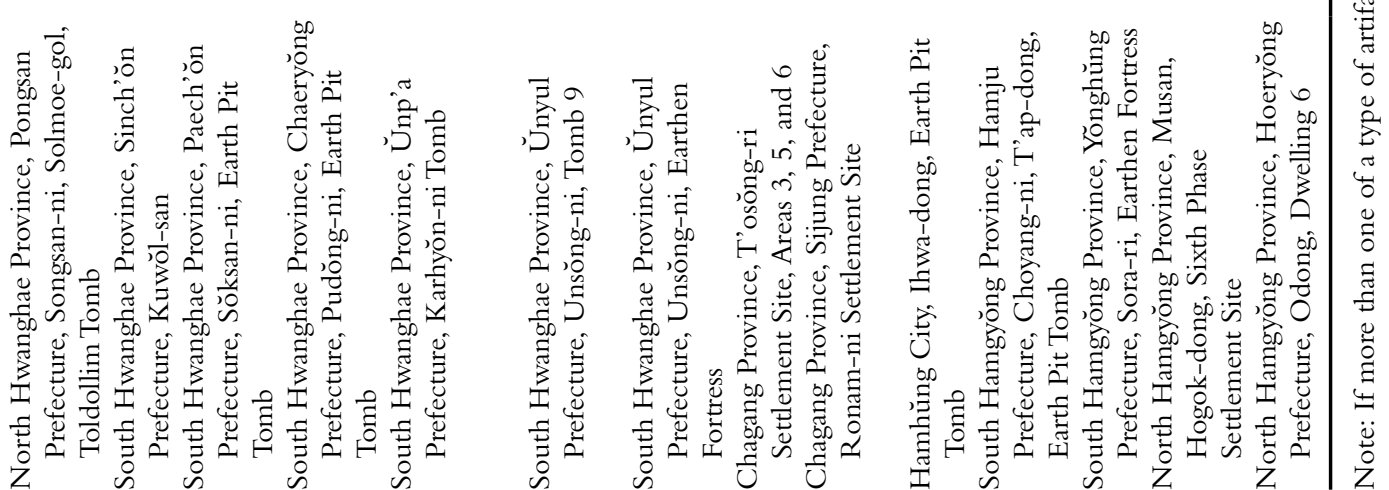




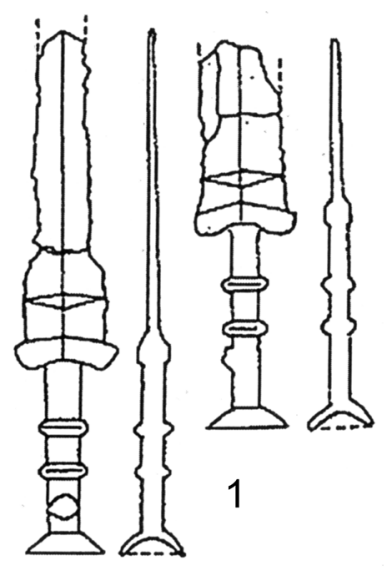

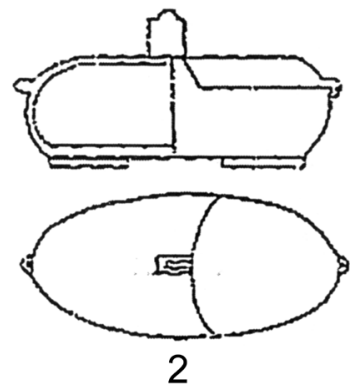

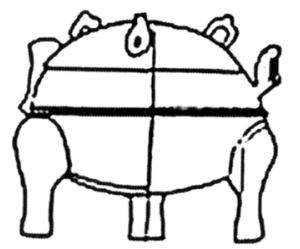

3
Fig. 5. Bronze products from northeastern Korea in the third to second centuries B.C. 1 Eastern Zhou swords in Kosan-ni; 2 bronze vessels; 3 ding vessel.

Interestingly, these items were discovered with indigenous products, such as slender daggers, fine line mirrors, and bells. Considering both the small number of imported bronze goods and the artifact assemblages discovered in situ, it is clear that the Han bronze products were not the principal items of import in Wiman Chosŏn. Instead, indigenous-style bronze goods still dominated in terms of the overall bronze-ware production and exchange landscape. It seems that the local people of Wiman Choson traded with Han, while continuing and further developing their own cultural traditions based on bronze objects that had been part of their culture since the earlier Bronze Age.

There are other cases of bronze imports that need to be examined, for example the swords of Eastern Zhou 東周 and the bronze ding 鼎, which are believed to have been discovered in Pyongyang and Hwanghae Province. In the case of the Eastern Zhou swords, there were no other iron goods found with the swords, but these might have been traded before the second century B.C. One of the Eastern Zhou swords was discovered with a dagger axe inscribed with a reign year of the first emperor of Qin, (the 25 th year, or 222 B.C.), along with a slender dagger, and a bronze axe. Another sword was discovered with a slender dagger and its hilt in Kosan-ni, Hwanghae Province. An early Han bronze ding was discovered from the wooden chamber in tomb 8 in Chŏngbaek-tong, Pyongyang (SKKY 1983). Even though this ding is believed to date to the late Warring States period or early Han, the date of import is not clear, though it probably occurred during the second or first centuries B.C. (Chŏng 1996:149-151).

Ceramics - Han pottery in the earlier Warring States style is one of the main imports in the Wiman Choson region. Ceramics fired at high temperatures have been discovered along with Han coins at most sites dating to the Wiman Chosonn era. The main category is vessels used for daily living, including types such as the guan 罐 pot, dou 豆 mounted cup, bo 鉢 bowl, zeng 甑 steamer, $h u$ 嗀 jar, and $f u$ 釜 caldron. Approximately 10,000 vessels and potsherds were discovered in the Lianhuabu site in Fushun east of the Liao River, almost all dating to the Han or Warring States periods. These ceramics are mainly gray colored, indicating a high level of hardness due to being fired 
at high temperatures. The main surface pattern is cord marking (shengwen 繩紋), but there are also linear patterns (xuanwen 弦紋), perforated lines (liandianwen 連点紋), sawtooth patterns ( juchiwen 鋸齒文), and raised bands (duiwen 堆紋) decorating the surfaces. Some vessels have no surface decoration.

The number of Han-style objects declines with increasing distance from the central plains. Even though Han pottery still dominates the assemblages, some objects are identifiable as indigenous forms. The shapes of indigenous vessels are significantly different from Han styles; they are manufactured from combined raw local materials such as clay and talcum powder or sand, and they were made with relatively low firing temperatures. In the northwestern part of the Korean Peninsula, large quantities of brown colored ceramics of indigenous style have been recorded, including pots, steamers, shallow bowls, deep bowls, plates, and pedestal bowls. These vessels were fired in relatively uncontrolled low temperatures, resulting in the brownish surface color. In addition, red and black polished vessels, which had been manufactured in this region starting in the Early Bronze Age, have been discovered together with Hanstyle pottery.

Roof Tiles - It is not clear whether roof tiles were a trade item in Wiman Chosŏn because roof tiles dated precisely to the second century B.C. have not yet been reported found in the northwestern part of the Korean Peninsula. Roof tiles of the Warring States period are distributed in the region east of the Liao River, but do not extend beyond the Yalu River valley. Roof tiles and end tiles with inscriptions such as chunqiu wansui 春秋萬歲, meaning “longevity," and leyang 樂央, meaning “happiness and longevity," or patterns including animal figures and plants indicating they were fashioned during the Warring States period are distributed east of the Liao River and the Liaodong Peninsula. These kinds of roof tiles have not yet been discovered south of the Yalu River valley. The only data we can presently bring into this discussion are the gray and red roof tiles discovered in association with indigenous-style pottery at a few earthen-walled sites, such as Nangnang, Chungam-dong, Unsŏng-ni, and Ch'ŏngsanni in the Pyongyang area (Nam 1996a, 1996b, 1999). These sites are believed to have been established in the third to the second centuries B.C. ${ }^{10}$ Another type of roof tile was discovered in North P'yŏngan Province, and convex and concave roof tiles and broken fragments of end tiles were unearthed at Tansan-ni in Pakch'ŏn Prefecture (CKPPW 1996: 83). These tiles date to before the Wiman Chosŏn era. This evidence suggests that the geographic and perhaps cultural boundary of roof tile use was the Yalu River prior to the second century B.C.

Significantly, roof tiles have not been discovered with Han coins, but they also have not been unearthed from sites with iron goods in the Korean Peninsula in this period. Even in Pyongyang, which is believed to have been the capital of Wiman Chosón and Old Choson, there are no roof tiles dating to before the second century B.C. Given the almost certain identity of Pyongyang as the capital of both Wiman Chosŏn and Old Choson, there is a need to address the question of whether Old Choson and Wiman Chosŏn ever used roof tiles and whether roof tiles securely dated to prior to the first century B.C. have been discovered in the above-mentioned earthen-wall sites.

Glass Beads-It is necessary to include studies of imported glass products in order to provide a more comprehensive view of interactions among emerging complex societies in the Korean Peninsula. Glass, jade, and jasper beads have been discovered in the northwestern part of the Korean Peninsula. Among them were glass beads that 
were clearly imported to Wiman Chosonn. Glass beads were discovered at the Ronamni dwelling site in Chagang Province and at the Karhyŏn-dong tomb and Unsong-ni tomb 9 in the South Hwanghae Province. ${ }^{11}$ The beads from the first two sites are common round beads; the others are rings. They are all made of glass in various colors.

Recently, research on glassware excavated in the southern Korean Peninsula has been conducted, but research on the northern part of the peninsula is limited due to lack of access. A chemical analysis of beads found in the north shows that they are similar to those found in the southern part of the Korean Peninsula (CKPPW 1996). Given that glass manufacture in Asia was developed based on a Roman model and that the technology of glass manufacture in ancient China was introduced to Korea, the glass beads can be seen as representing indirect contact between Western societies and Wiman Chosŏn. Based on the presence of glass beads in the Museum of Shenyang in Liaoning Province, China, and in Lelang-style tombs, one possibility is that they were imported via a route from northeastern China. How they were imported, that is, by whom, through what means of transport, and from which locations, remains to be investigated.

\section{Exports to Chin from Wiman Chosón}

Iron Products-Iron goods such as axes, sickles, gravers, and chisels found in the southern part of the Korean Peninsula were made in the style common to Yan and Han China (Fig. 6). They were probably imported to Chin via Wiman Chosŏn. The main items were woodworking tools (see Figure 4 above). Weaponry finds are rare, there being only three cases: a sword, an arrowhead, and a small fragment of a sword. The number of sites and artifacts found in the southern part of the peninsula are fewer than those of the northwestern part of the peninsula, however. The items are also relatively simple in style.

Representative iron goods used in trade have been found at Soso-ri in Tangjin, Hapsongni in Puyŏ, Wŏnbung-ni in Nonsan, Namyang-ni in Changsu, Sindong-ni in Iksan, Ipsil-li in Kyŏngju, and Naesŏng in Pusan (Table 2). There are different views

\section{Number in each item}

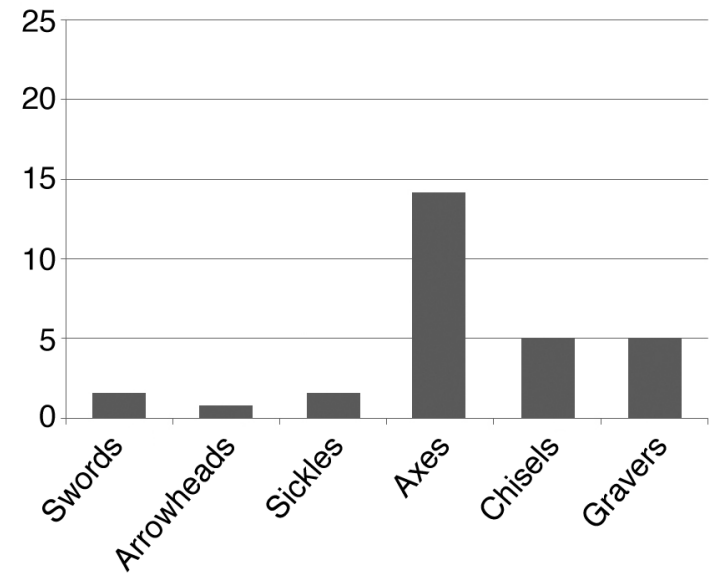

Fig. 6. Categories of iron goods manufactured in the style common to Yan and Han China found in the southern Korean Peninsula, most likely imported to Chin via Wiman Chosŏn. 


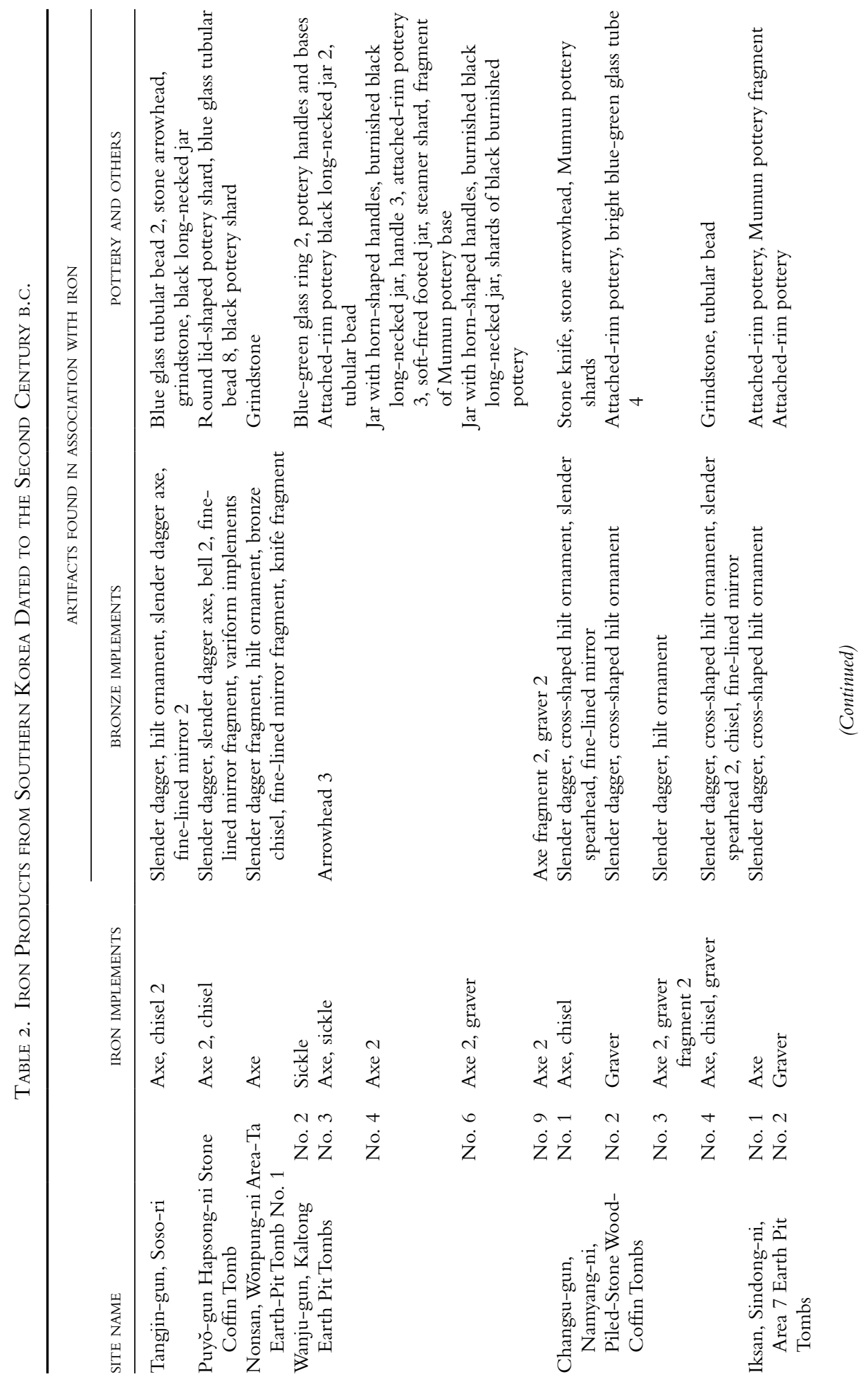




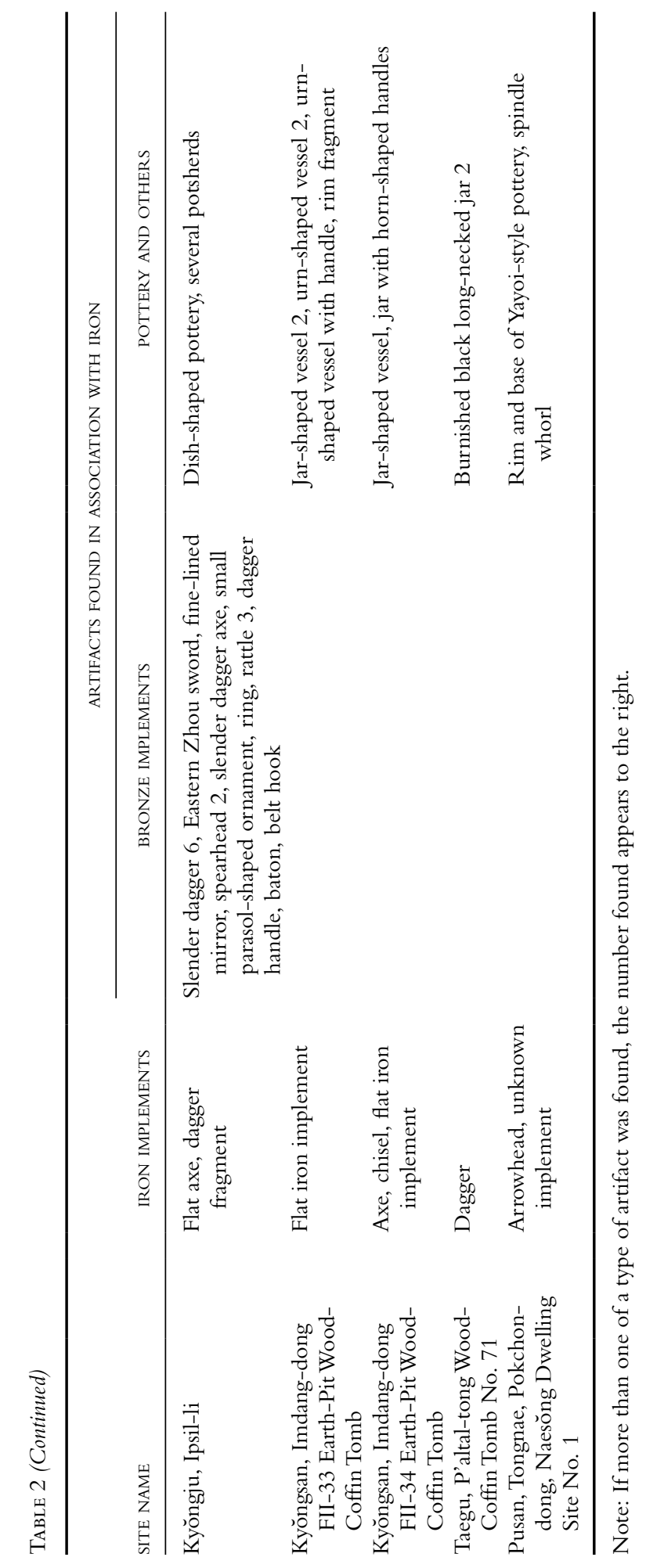


about the dates of items from the Ipsil-li sites, but given that the artifact assemblages such as the dagger and fine-lined mirror are similar to those found at Soso-ri and Hapsong-ni, this site can be dated to the second century B.C. Even though the date of each feature in the Kaltong site is slightly different, the primary period of site use was the second century B.C. (HMY 2009:113-117).

Most of the sites are geographically distributed around the Kŭm River valley and in a few regions such as Taegu and Kyŏngsan located in the southeastern part of the peninsula. The characteristics of iron goods are similar to those in North P'yŏngan Province, showing relations with Sejung-ni in Yongbyŏn and Ronam-ni in Chagang Province. Moreover, the form of some iron goods (e.g., slender daggers, slender halberds, and spears) suggests they were produced with a forging technology believed to have been a local method of production.

Bronze Products-Bronze goods imported into Chin can be classified into two categories: (1) Han Chinese products traded through Wiman Chosŏn; and (2) products made in Wiman Chosŏn. The latter include slender daggers, fine-lined mirrors, and slender halberds; the former include Han mirrors, ding vessels, and Eastern Zhou swords (Fig. 7). Hapsong-ni in Puyŏ, Soso-ri in Tangjin, Ipsil-li in Kyŏngju, and Ch'opo-ri in Hamp'yŏng are representative sites. Excepting P'yŏngjang-ni in Iksan and Ch'opo-ri in Hamp'yŏng, most of the above sites also yielded Warring States-style iron goods in situ.

Fine-lined mirrors are said to constitute archaeological evidence demonstrating an active trade sphere between Wiman Chosŏn and polities in the southern Korean Peninsula. Not only materials but technology of manufacture and presence of highly skilled specialists support this contention (Pak 2001; Yi 2002). The coarse-lined predecessors of fine-lined mirrors, associated with each other by typological similarity, are distributed intensively in the Taedong River and Kŭm River basins. The fine-lined mirror forms started flowing significantly into the south-central part of the peninsula after the second century в.C.Yi (2002) proposes that this distribution pattern is related to trade with Wiman Chosŏn. Other archaeologists such as Chŏn (1994:293-295) argue that the fine-lined mirrors made in the Kŭm River valley were traded to the Taedong River valley. If this was the case, then Wiman Chosonn imported the mirrors from Chin.

A Han mirror was discovered together with slender daggers at the P'yŏngjang-ni site in Iksan. It is the only specimen of its type found in southern Korea. This mirror was fashioned in the early Han, but the specific period in which the mirror was traded is not clear. Even though there are arguments about the date, the site and burial goods with which it is associated have been dated to the second century B.C. based on the in situ artifacts and the style of the tomb.

Two ding vessels were discovered in Hadae tomb 23 in Ulsan and Yangdongni tomb 322 in Kimhae, but the trading route and timing is unclear. Chinese scholars Li and Wang (2002:16-19) suggest that the ding vessel from Hadae came directly from Qi 齊 (located in Shandong) about the third century B.C., while the ding from Yangdong-ni was made in the late Warring States period. They assert that refugees brought them into the Korean Peninsula when they fled there from polities such as Qi. However, Chŏng (1996:149-151) argues that the ding vessel from Hadae was made and exported from Guangzhou, while the ding vessel from Yangdong-ni was manufactured in Chang'an during the early Western Han and later imported to the southern part of the Korean Peninsula by way of Lelang. 


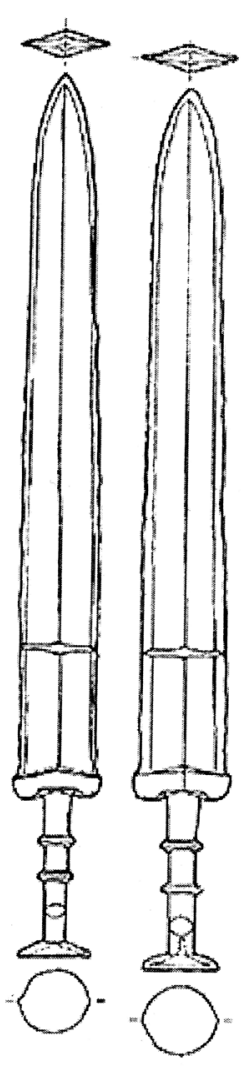

1
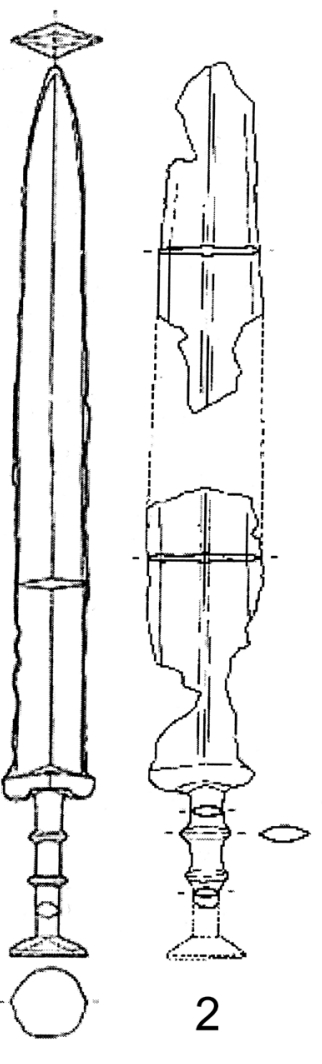

2

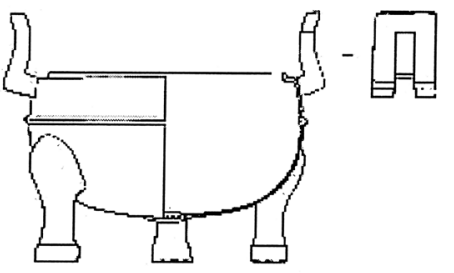

5

Fig. 7. Bronze goods imported into Chin, including Han Chinese products traded through Wiman Chosŏn. 1, 2: Eastern Zhou swords (1 Sangnim-ni, 2 Ch'opo-ri); 3: Han mirror in P'yŏngjang-ni; 4, 5: ding vessels (4 Hadae, 5 Yangdong-ni).

Eastern Zhou swords were discovered at Sangnim-ni in Wanju, Sillyŏngni in Iksan, Ch'opo-ri in Hamp'yŏng, and Ipsil-li in Kyŏngju. Two Eastern Zhou swords are believed to have come from South Ch'ungch’ŏng Province and Kyŏngju. Most swords are believed to have been transferred to these regions via Wiman Chosŏn. A few are considered to be local products or direct imports from the central plains of China. For example, Li and Wang (2002:12-15) suggest that the swords in Sangnim-ni were made in Qi in the late fourth century B.C. and were traded directly through a marine route, while Chŏng (2001) considers the swords in Wanju to be local products manufactured in imitation of those from Eastern Zhou. In general, most imported bronze items came from large tombs with luxury burial goods, implying that these items had symbolic meaning and were traded among elites.

Ceramics - It is uncertain which kinds of ceramics were exported from Wiman Chosŏn to Chin. Pottery with clay band decoration with triangular cross sections (samgakhyong 
ch'omt'odae t'ogi) seems to be related to trade between these polities, however, because it suggests the adoption of a new method of manufacture, namely, the paddling ( $t$ 'anal) method, which refines the surface by pounding the body of the ceramic. Vessels made using this new technique were fired in well-structured, tightly closed chamber kilns at firing temperatures higher than $1000^{\circ} \mathrm{C}$. This technique is believed to have been introduced to the southern part of the peninsula along with iron technology. Representative sites showing evidence of this pottery technique include Kun'gong-ni in Haenam, Nǔk-to in Sach'ŏn, Kaltong in Wanju, Kawaji in Ilsan, Oyido in Sihŭng, Sinch'ang-dong in Kwangju, and Ch'ilgok in North Kyŏngsang Province.

Although this type of pottery was introduced to the southern part of the peninsula during the Wiman Chosŏn era, the same type of pottery has not been reported in the northern part of the Korean Peninsula. ${ }^{12}$ In addition, it has not been ascertained that an earlier type of this pottery featuring an attached rim with a round cross section (wornhyong ch'omt'odae t'ogi) has been discovered in Pyongyang. It is therefore too early to say that pottery with clay band decorations with triangular cross sections was traded from Wiman Chosŏn.

Due to the ambiguity surrounding these types of pottery, different scholars have proposed different routes of transmission. Yi (1994) suggests that pottery with clay band decoration with round cross sections could have been directly introduced from the Liaoning region to the southern peninsula, having bypassed the northern part of the peninsula. If this hypothesis is true, the pottery with clay band decoration with triangular cross sections could have developed at the local level. However, the paddling (t'anal) method was fully advanced in the south only around the turn of the Common Era, which problematizes the hypothesis (Yi 2000:58-60).

Nevertheless, we should not exclude the possibility that this new technology was connected with Wiman Chosŏn, since its stylistic predecessor (i.e., attached round rim pottery) has been unearthed in the northern part of the Yalu River valley. It is necessary to determine whether the introduction of the pottery characterized by clay band decoration with triangular cross sections was influenced by an external agency, that is, whether it derived from the transference of ideas or people (migrants) from the north.

Glass Beads - Glass beads and rings are typical exotic luxury goods found in the southern part of the Korean Peninsula, although their routes of entry have not yet been determined. Glass beads were discovered at Soso-ri in Tangjin, Hapsong-ni in Puyŏ, and Namyang-ni in Changsu. Glass rings and tubular beads were discovered at Kaltong tomb 2 in Wanju, Sinp'ung in Wanju, and Changhyŏn-dong in Ulsan. Glass tubular beads may be considered local products, produced in imitation of the green jades of the Bronze Age using imported raw material originating from Han through Wiman Chosŏn (Yi 1993:446-448).

Most glass goods were discovered in context with local bronze products (e.g., slender daggers) and fine-lined mirrors in various tombs. Unfortunately, no direct archaeological evidence has been discovered to show that these items came from Wiman Chosŏn. However, given the existence of the same style of glass beads in Wiman Chosŏn (addressed above) and the same chemical component of glass beads in China (Kim et al. 2005), we can hypothesize that these glass products were imported along with iron goods from Han via Wiman Chosŏn. 


\section{THE BUFFER ZONE TRADE OF WIMAN CHOSŎN}

As reviewed above, iron weaponry and farming tools, Han-style hard-fired pottery, vessels and harnesses for horses and carriages, bronze mirrors and vessels, glass beads, and other objects were traded into Wiman Choson from Han. A few iron products (mainly woodworking tools), jades, glass goods, and other items were secondarily exported from Wiman Choson to polities such as Chin in the southern part of the Korean Peninsula (Fig. 8). These trade items were intensively distributed in Pyongyang and nearby regions, but only small quantities of simple iron goods, such as axes,

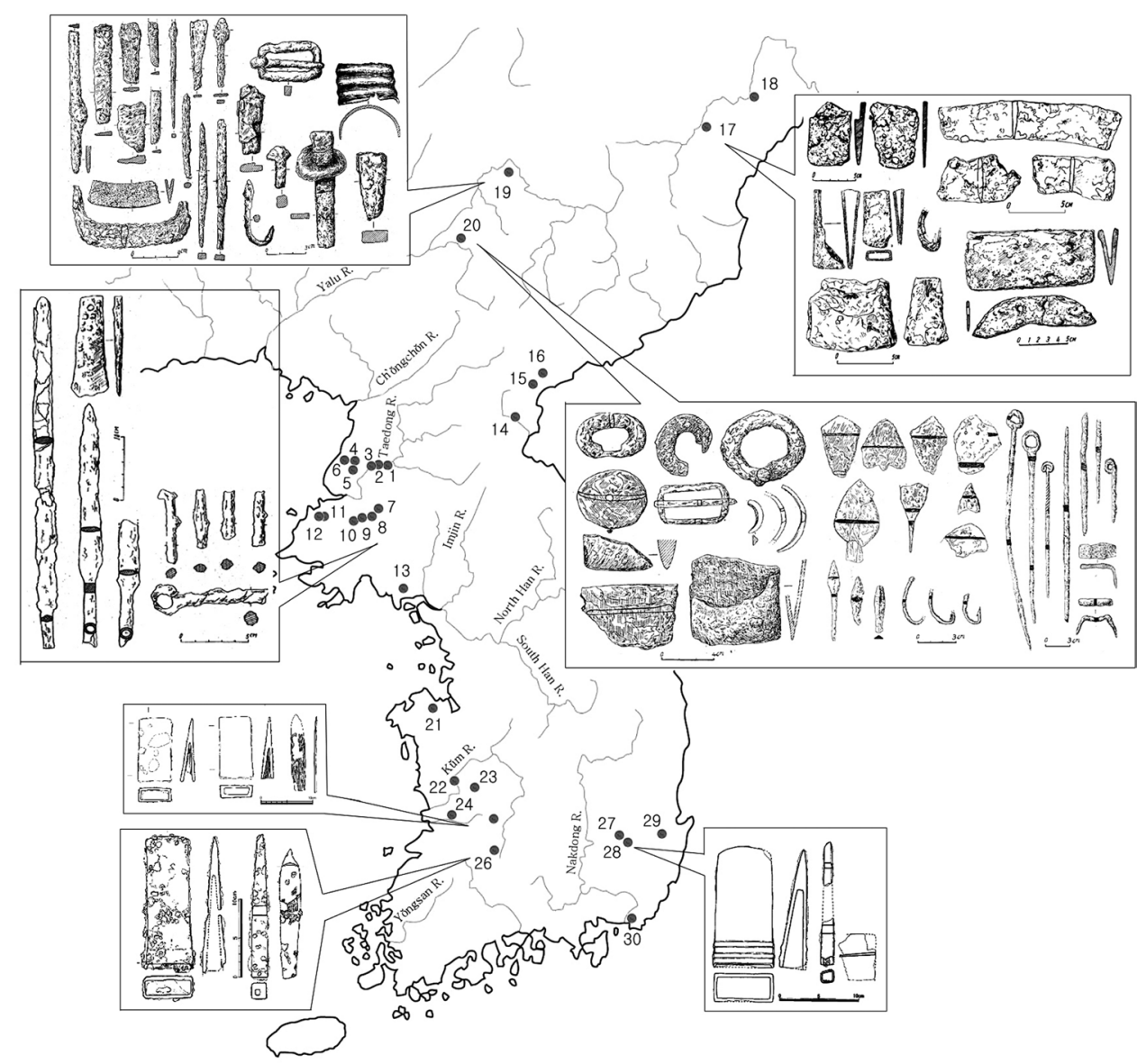

Fig. 8. The distribution of iron products on the Korean Peninsula in the second century BC. 1 Pyongyang, Nangnang-ni; 2 Pyongyang Chŏngbaek-tong; 3 Pyongyang T'osŏng-dong; 4 South P'yŏngan, Taedong-gun; 5 South P'yŏngan, Kangsŏ-gun; 6 South P'yŏngan, Chŭngsan-gun; 7 South Hwanghae, Pongsan-gun; 8 South Hwanghae, Ünp'a-gun; 9 South Hwanghae, Chaeryŏng-gun; 10 South Hwanghae, Sinch'ŏn-gun; 11 South Hwanghae, Unyul-gun; 12 South Hwanghae, Unsŏng-ni; 13 South Hwanghae, Paech'ŏn-gun; 14 South Hamgyŏng, Yonghŭng-gun; 15 South Hamgyŏng, Hamju-gun; 16 South Hamgyŏng, Hamhŭng-si; 17 North Hamgyŏng, Musan-si; 18 North Hamgyŏng, Hǔiryŏng-gun; 19 Chagang, T'osŏng-ni; 20 Chagang, Sijung-gun; 21 South Ch'ungch'ŏng, Tangjin-gun; 22 South Ch'ungch'ơng, Puyŏ-si; 23 South Ch'ungch'óng, Nonsan; 24 North Chŏlla, Iksan-si; 25 North Chŏlla, Wanju-gun; 26 North Chŏlla, Changsu-gun; 27 North Kyŏngsang, Taegu-si; 28 North Kyŏngsang, Kyŏngsan-si; 29 North Kyŏngsang, Kyŏngju-si; 30 South Kyŏngsang, Pusan-si. 
chisels, and forged gravers, were distributed in the southern part of the peninsula. In short, the number of imports declines beyond the Wiman Choson territory. This circumstance is much clearer with coins. Coins were imported only by Wiman Choson and did not spread into the southern part of the Korean Peninsula during that era. Figure 9 shows coin distribution before and after the Wiman Chosŏn era.

The larger issue is how to interpret a set of patterns that includes a limited distribution of trade items, their limited function as simple tools, and the absence of coins in the southern part of the peninsula. In particular, what does the fact that almost all of the imports were found associated with indigenous products (e.g., slender bronze daggers) and fine-lined mirrors, mean for reconstructing the economic relationships and political power parameters of the Wiman Chosŏn trade system? A one-dimensional view might see the diminishing quantity of imports with distance from the central plains of China as an uncomplicated function of Han trade dominance and influence, but this would ignore the complex interactions among polities and the dynamic power relations of exchange that shape these material and cultural transactions. The analysis of sites earlier in this paper suggests that the polities in the northern part of the Korean Peninsula that were importing iron products partly adopted Han's iron material culture along with ideological elements related to power, status, centralization of economic productivity, and military might. They simultaneously amalgamated these with indigenous cultural meanings and structures that in turn affected and melded with those of other trade partners. In addition, after the collapse of Wiman Chosŏn, Han products such as Han-style pottery and coins started flowing into developing centers in the southern part of the peninsula without regard for distance; this pattern indicates some type of restricted trade was associated with political centralization. Therefore, we should not ignore the lack of iron products and coins in the earlier period as reflecting a lower stage of political or economic development, but instead examine the circumstances under which the southern polities might have multilayered foreign trade relations.

These fairly complex circumstances require that more in-depth analysis of comparative data from this region be conducted to settle the question of what kind of trade took place in these regions and the probable power dynamics associated with this trade. I propose the Buffer Zone Trade theory to elucidate these unique circumstances and explain how trade was structured during the Wiman Choson era (Park 2009). ${ }^{13}$

As mentioned above, the Shiji and Sanguozhi both state that many migrants from the central plains fled to Old Chosŏn and Wiman Chosŏn, allowing Wiman Chosŏn to gain political and economic ascendancy. Wiman Chosŏn further developed as a state by becoming the predominant trading partner with Han. Its role as a trade intermediary between Han and other emerging complex societies on the peninsula facilitated its political and economic expansion in the region. According to the Xiongnu 匈奴列傳 account in the Shiji, at that time Han and neighboring states such as Nanyue 南越 and Xiongnu officially and unofficially traded in the form of gift exchange (“seasonal greetings”歲幣) and border markets 關市. ${ }^{14}$ Wiman Chosŏn seems to have engaged in similar relations with Han. Wiman Chosŏn was able to establish a monopoly over trade with Han on the Korean Peninsula, thereby controlling the polities in the periphery.

According to these historical documents, a formal agreement between Wiman Chosŏn and Han stipulated that Han would offer various items (notably iron weapons 
$\Delta$ Before the Collapse of Wiman Chosón

O After the Collapse of Wiman Chosǒn

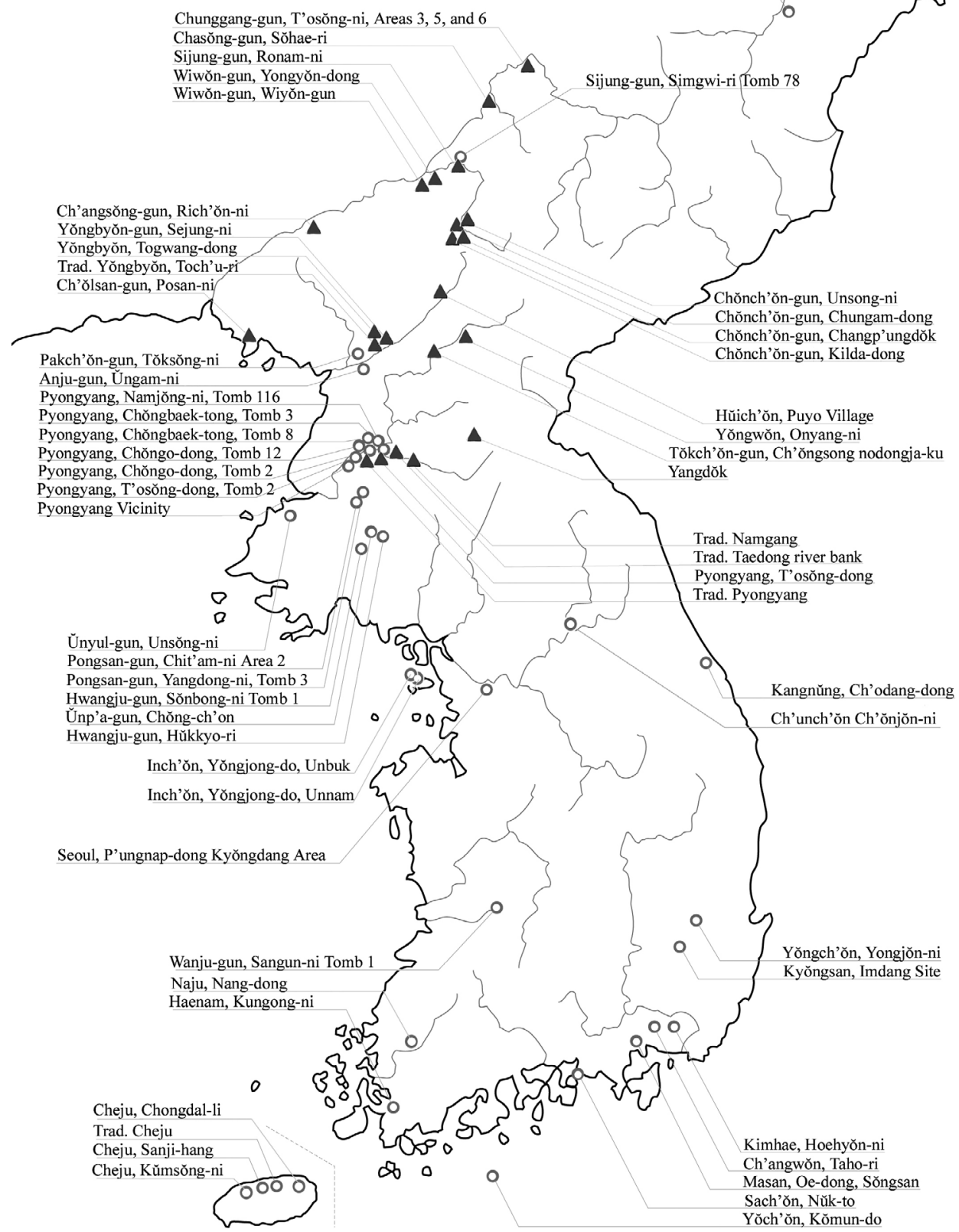

Fig. 9. The distribution of coins before and after of the collapse of Wiman Chosŏn. 


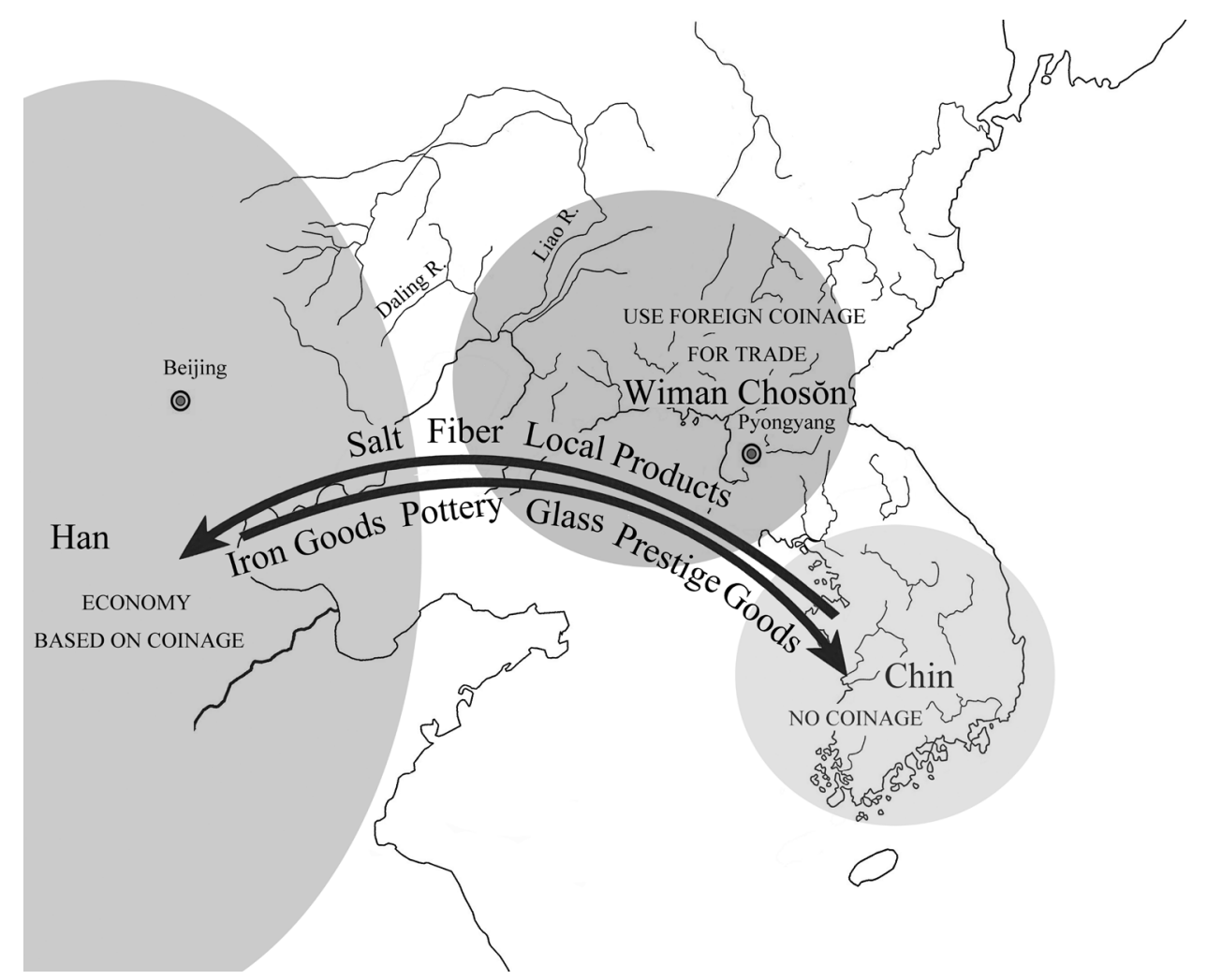

Fig. 10. Schematic map of the flow of goods in Wiman Chosŏn's Buffer Zone Trade system.

and prestige goods) in return for Wiman Chosŏn agreeing to allow neighboring chiefs from the periphery to pay tribute to the emperor of Han. ${ }^{15}$ The agreement seemed to have been formalized between 193 and 192 B.C. (KPW 1989:91). Han might have been prompted to make the agreement with Wiman because it urgently needed to settle its chaotic borders following the reunification of the central plains after the collapse of Qin. Han probably also looked to expand revenues from trade by coordinating with a foreign authority such as Wiman Chosŏn. As a result of the agreement, Wiman Chosŏn obtained weaponry it needed to attack and subjugate neighboring polities (some of which surrendered of their own accord), thus expanding its local political and militaristic control over and access to external resources. ${ }^{16}$ Figure 10 illustrates Wiman Chosŏn's buffer zone trade system.

The buffer zone trade system ensured that Han products were only selectively transported to neighboring elites. As mentioned above, approximately from the third to the second centuries B.C., ancient Chinese coins started flowing into southwestern Manchuria and the northwestern part of the Korean Peninsula, where Old Choson and Wiman Choson were historically active. There was no distribution of these currencies farther south on the peninsula until the late second century B.C., when Wiman Chosŏn's King Ugo broke the agreement by blocking neighboring chiefs from visiting Han. Initially, Han tried to reconcile with Wiman Chosŏn through diplomatic means, but King Ugŏ rejected such attempts. Han finally raided the capital of Wiman 
Chosŏn. The subsequent war lasted for one year, ending with Wiman Chosŏn's collapse in 108 B.C. After Wiman Chosŏn collapsed, coins emerged in the southern regions. They then became widely distributed in Seoul, Chŏlla Province, Kyŏngsang Province, Kangwon Province, and even Cheju. Other Han products dramatically increased in the south, including iron goods, bronze goods, and pottery. At the same time, historical documents show that the representative polity in the southern peninsula shifted from Chin to the so-called “Three Han” confederations: Mahan (馬), Pyŏnhan (弁韓), and Chinhan (辰韓).

These transformations in the south-central Korean Peninsula may have been the result of the disappearance of the buffer zone trade formerly routed through Wiman Chosŏn. After Wiman Chosŏn collapsed, Han established commanderies on the peninsula that enabled polities in the south to contact Han directly. As trade with Han reached further into each small peripheral polity, it might have stimulated both regional integration and partition.

To summarize, Han needed to pacify the border and reinforce its central political position; it made strategic use of Wiman Chosŏn (located in its northeastern border) as a trade ally to provide stability to the region. The resulting trade system likely softened the impact of Han's advanced civilization on the periphery by buffering distant polities from undergoing rapid cultural transformation and even collapse. It more explicitly enabled Wiman Choson, the intermediary polity, to acquire useful technologies that advanced its economic and political aims in the local area. Its monopoly over trade in advanced Han products, described as a "wealth of weaponry and luxury (兵威財物)" in historical documents, allowed Wiman Chosŏn to attain a superior position vis-à-vis local elites. ${ }^{17}$

Chin, in the southern part of the Korean Peninsula, was not at the scale and level of complexity that we would usually associate with a state. Nevertheless, the buffer zone trade relationship with Wiman Chosŏn enabled Chin leaders to obtain needed exotic luxury goods as a form of political currency. That is, these goods were used to symbolically display Chin power and maintain control over its people. Therefore, Chin may not have needed Han coins as a medium of exchange for imports until after Wiman Choson collapsed and the three Han confederations began trading directly with Han China through the commanderies, although Chin seems to have used the coins as another prestige good rather than as a medium for economic transaction.

The arguments that constitute the buffer zone trade hypothesis are further supported by comparing archaeological data from before and after the Wiman Chosŏn era. After the collapse of Wiman Choson, there were dramatic changes in the material culture of the Korean Peninsula. In the northern part of the peninsula, Han and Warring States coins, which had been dispersed over a wide area around the YaluTaedong River valleys, became concentrated primarily near Pyongyang after the collapse of Wiman Chosŏn. Moreover, Han-style tombs and artifacts increased in the above areas. In the southern part of the peninsula, Han coins were first introduced after the collapse of Wiman Choson and Han-style artifacts such as Lelang-style pottery and mirrors increased. Iron goods developed significantly in the south, both in terms of quantity and technical sophistication, while the indigenous "Slender Bronze Dagger" culture declined. Most interestingly, there was also a shift in power, as the Three Han replaced Chin.

In proposing the Buffer Zone Trade theory, we must account for another critical point, namely, what made Wiman Chosŏn a semi-core. This question concerns the 
identity and nature of Wiman Chosŏn as a state, which is related to why King Chun 準 of Old Chosonn trusted Wiman to settle his western border and titled him Boshi 博士 (Erudite). Three historical circumstances account for this: (1) international disorder in the late Qin and early Han period; (2) the geographical location of Wiman Chosŏn; and (3) the formation of Wiman Choson out of allied immigrant and indigenous groups.

The Shiji and Sanguozhi state that when Qin and Han were fighting each other, tens of thousands of Yan, Qi, and Zhao refugees fled to Old Chosón. Wiman and his people were amongst the Yan refugees. According to historical sources, Wiman suggested that he and his people serve as a frontier army to protect Old Chosŏn against attack by Han. King Chun agreed and allowed Wiman and his people to live in the western border area along with migrants from Qin and Han. Wiman used his position as governor of the western border to obtain enough power to seize the throne a few years later; he became king of his own polity, Wiman Chosŏn.

Why did Chun trust Wiman, a foreign refugee? Cross-cultural research on imperial strategies for trade in expanding state or empires shows that incorporating groups of foreigners (referred to as "stranger communities") within one's polity could be economically useful to local rulers for several reasons (Azary 1980; Stein 1999; Yambert 1981). In many agrarian or pastoral societies, exchange was viewed as a suspicious and low-status, albeit necessary, activity that was best left to outsiders or socially inferior groups within the polity; most exchange activities were therefore carried out by foreign people. These foreign groups were tolerated, but restricted in their activities and denied access to the state center (Azary 1980:443-449). Sponsoring and taxing trade diasporas provided an easy way for rulers in the host communities to increase their own wealth without having to go through the conflict inherent in restructuring power relationships within their own community (Yambert 1981). The foreign groups meanwhile maintained distinctive cultural identities and independent trade monopolies authorized by local rulers. In some cases, a foreign merchant group expanded its own power and dominated the local political elite, to become the new ruling class (Stein 1999). Wiman's group could be considered a migrant group supported by King Chun, even though it is unclear whether this group initially functioned as a trade emissary to him.

Wiman Chosón next had the advantage of geographic location because it was at a major transportation point connecting the central plains of China with the southern Korean Peninsula. When Wiman Chosŏn was in its golden age, it expanded westward toward Liaodong and northeast to the maritime province of Siberia through North Hamgyong Province. The marine route connected it to the capital of Han via the Shandong Peninsula, following the islands and the coastal region of the Korean Peninsula. In other words, Wiman Chosŏn was a major stopping point on the Han trade routes.

Finally, Wiman Chosŏn was a state operated by alliances between immigrant elites and indigenous elites who had served Old Choson. As noted at the beginning of this article, ruling classes consisted of immigrants such as the Sang 相, Kyŏng 卿, and the Generals 將軍 along with local populations such as the Piwang 裨王 and Taesin 大臣. These political and geographical circumstances enabled Wiman Chosŏn, a major trader and political mediator, to play the "semi-core" role in an intermediary or "buffer zone" trade system. 


\section{CONCLUSIONS}

In this article, I have used the Buffer Zone Trade theory to explain various aspects of the archaeological record in second and first century B.C. Korea. Specifically, I have sought to explain: (1) why Han coins were not transmitted to the southern part of the Korean Peninsula until the first century B.C. (after the fall of Wiman Chosonn); and (2) why advanced iron implements, including weapons, were distributed in the northwestern and northeastern parts of the peninsula during the Wiman Choson period, while in the southern regions only simple iron axes and chisels were transmitted in limited quantities. While scholars in Korea have shown interest in the system of trade utilized in Wiman Choson, they have not paid sufficient attention to the discrepancies in the distribution of iron goods between the northern and southern parts of the peninsula during the Wiman Choson period or to the changes observed in the archaeological record before and after the fall of Wiman Choson. As demonstrated in this article, comparative analysis of the archaeological data clarifies the nature of the trade system utilized in Wiman Choson and shows that it fits the Buffer Zone Trade model.

Clearly, the changing aspects of archaeological data after the collapse of Wiman Chosŏn indicate that Wiman Chosŏn, occupying the gateway from the central plains to the southern part of the Korean Peninsula or the Japanese archipelago, helped shape the exchange system in Northeast Asia in the second century B.C. The Buffer Zone Trade model is suggested as a way to understand the nature of the trade system and political economy in Wiman Choson both in functional and material terms. Wiman Chosŏn mainly imported iron products and high-fired pottery from Han and used Han coins. These exotic, high-prestige Han products were delivered in small numbers by Wiman Chosŏn to polities in the periphery, presumably allowing these smallerscale polities to expand their power and territory. However, analyses of coin distribution suggest that these polities did not use coins as currencies for domestic transactions with Wiman Chosŏn. After Wiman Chosonn's collapse, there was no longer a buffer zone for trade in the region. The peripheral polities (the Three Han) located south of the formerWiman Chosón could now trade directly with Chinese Han through Han's commanderies. This marked the beginning of a totally different trade sphere.

Wiman Chosón achieved a monopoly over trade with Han and controlled the trade with polities in the periphery, which allowed it to act as a semi-core. Its identity as a state comprised of migrants allied with locals led it to practice a form of buffer zone trade between the Han core and the Chin periphery. Both Wiman Chosón and Han took advantage of this situation for their own purposes, Han as the political and economic center and Wiman Chosŏn as semi-periphery to Han and semi-core to its neighboring polities. These neighboring polities in turn used foreign trade to strengthen border security and promote the political currency needed to maintain local rule.

\section{ACKNOWLEDGMENTS}

I was able to complete this article with help from many scholars in the Department of Anthropology and Archaeology, Harvard University. I would like to thank Dr. Mark Byington, who read my paper very thoughtfully from beginning to end. I would also like to thank Professor C. C. Lamberg-Karlovsky and Professor Rowan Flad, who provided very helpful comments. And I would like to acknowledge my appreciation to Dr. Martin Bale of Yale University, and Weng Cheong Lam in the Department of Anthropology and Archaeology, Harvard University. 


\section{NOTES}

1. In this article, the term Old Choson refers to the polity prior to the attack by Wiman. This polity dates from approximately the eleventh century B.C. to the late second century B.C. The term Wiman Choson refers to the state following Wiman's takeover, dating from 195 to 108 B.C.

2. Shiji 史記, or the Records of the Grand Historian, was written from 109 to 91 в.C. This text covers the time of the Yellow Emperor through late B.c. times. Sanguozhi 三國志, the Records of the Three Kingdoms, covers the history of the late Eastern Han Dynasty (c. 184-220 C.E.) and the Three Kingdoms period (220-280 c.E.). Both these texts include historical notes on neighboring societies such as Xiongnu, Nanyue, and Chosǒn.

3. Scholars have not reached consensus about the location of Chin. According to the Shiji 史記 and Zizhi tongjian 資治通鑑漢紀 13, Chin seems to have been located in the central and southern parts of the Korean Peninsula approximately by the second century B.C. However, descriptions differ among various editions of the Shiji. For example, the Jiaokan edition 校勘本 refers to "the various polities adjacent to Chinbŏn" (這番旁衆國), while the corresponding text in the Bona 百衲本 and Song (宋板本) editions refer to “the polity of Chin adjacent to Chinbŏn” (眞番旁辰國) (Yi 1997:262-263). As a temporary expedient, Chin is assumed to have embraced the central and southern sections of the peninsula in this paper.

4. The three Han polities were located in the southern third of the Korean Peninsula, with Mahan located in the west, Chinhan in the southeast, and Pyonhan in the south. Each of these three consisted of a number of distinctive minor polities, representing complex but pre-state social structures.

5. Sanguozhi 三國志 30 (Account of Han 韓傳, citing the Weilüe 魏略, a brief account of the Wei Dynasty): "After more than twenty years Chen [She] and Xiang [Yu] arose and the world was cast into chaos, then the people of Yan, Qi, and Zhao suffered hardships and gradually fled to [the Ko Chosŏn king] Chun. Chun then settled them in his western lands” (二十餘年而陳項起天下亂燕 齊趙民愁苦稍稍亡往準準乃置之於西方. Sanguozhi 三國志 30, (Account of Han 韓傳, citing the Weilüe 魏略).

6. Shiji 史記 115 (Account of Chosŏn 朝鮮列傳): “When the Yan king Lu Wan rebelled and went over to the Xiongnu, [Wi]man fled with over a thousand followers, tied his hair into a topknot and dressed in eastern barbarian clothing, and fled to the east. Leaving the frontier he crossed over the P'ae River and settled in the upper and lower embattlements in the land abandoned by Qin” (燕王盧綰 反人匈奴滿亡命聚黨千餘人魁結蠻夷服而東走出塞渡浿水居秦故空地上下鄣).

7. For example, Noin 路人, Hanŭm 韓陰, and Cham 參 each held the title Sang and Wanghyup 王唊 held the title Changgun; these are all considered to have been Han people. Chang 長, whose title was Piwang, and Seongki 成巳, who was a Taesin, may be regarded as indigenous people.

8. In the Western Han period, one $l i$ equaled approximately $415.8 \mathrm{~m}$, so $1000 l i$ would equal approximately $415,800 \mathrm{~m}$.

9. Shiji 史記 115 (Account of Chosŏn 朝鮮列傳): “[Wiman] invaded and subjugated the minor neighboring villages, and Chinbŏn and Imdun all came to subordinate themselves to him. [His] lands [then] extended for several thousand $l i$ ” (侵降其旁小邑眞番臨屯階來服屬方數千里).

10. Unfortunately, the archaeological reports do not specify the kinds of roof tiles discovered or provide chronological information.

11. Although the archaeological report states that the glass beads at Ronam-ni were excavated from the floor of a house, it is possible that they were mixed in with burial goods from a tomb that intruded upon the dwelling site.

12. As noted previously, no published archaeological reports describe the pottery found in Pyongyang or its vicinity.

13. The Shiji and Sanguozhi are reliable textual materials for garnering insights into the domestic and international situation surrounding Wiman Chosŏn. I do not focus on Old Chosŏn here because, although archaeological data indicate it had a trade system similar to that of Wiman Choson, surviving historical records relevant to Old Chosŏn are scarce.

14. "Seasonal greetings" was a formal event held at the beginning of the new year. To show their loyalty, each state's envoys brought local products to the royal palace to present to the king as gifts. At the same time, they transacted trade with merchants outside the palace.

15. According to Shiji 史記 115 (Account of Chosŏn 朝鮮列傳): “The governor of Liaodong made a pact making [Wi]man an outer vassal, [so that Wiman] would protect the barbarians beyond the frontier, preventing them from raiding the borders, and should the chiefs of the various barbarians wish to proceed to seek audience with the emperor, Wiman was not to obstruct them. ... [However], when the many polities [or the Chin polity] next to Chinbŏn wished to send a letter seeking audience with the emperor, [the last king of Wiman, King Wugŏ] would not let them pass (遼東太 守㴧約滿爲外臣保塞外蠻夷無使盗邊. 諸蠻夷君長欲入見天子勿得禁止……眞番旁衆(辰)國 欲上書見天子又擁閼不通).” 
16. As noted earlier, Wiman Chosŏn expanded its trade and ultimately its territory by a few thousand $l i$ 里 in every direction.

17. The Shiji 史記 115 (Account of Chosŏn 朝鮮列傳), states that: “Wiman signed an agreement and acquired a wealth of weaponry and luxury (會孝惠高后時天下初定. 遼東太守師約滿爲外臣保塞 外蠻夷無使盜邊諸蠻夷君長欲入見天子勿得禁止. 以聞上許之. 以故滿得兵威財物侵降其旁 小邑).”

\section{REFERENCES CITED}

AzARY, ViCTOR

1980 Traders and the center in Massina, Kong, and Samori's state. International Journal of African Historical Studies 13:420-456.

BANDy, MatTHEW S.

2005 Trade and social power in the Southern Titicaca Basin Formative. Archeological Papers of the American Anthropological Association 14:91-111. Archeology Division of the American Anthropological Association.

BinTLIFF, JOHN

1997 Regional survey, demography, and the rise of complex societies in the ancient Aegean: Coreperiphery, Neo-Malthusian, and other interpretive models. Journal of Field Archaeology $24: 1-38$

Ch'Oe, MONG-NyOng

1983 A study of state formation: The case of Wiman Chosŏn, in Kim Ch'óljun Paksa hwagap kinyöm sahak nonch'ong: 61-77, by Kim Ch’ŏljun Paksa Hwagap Kinyŏm Sahak Nonch'ong Kanheang Chunbi Wiwŏnhoe. Seoul: Jisik-Sanu'psa Press.

1985 The development of state and trade: The case of Wiman Chosŏn, in Ancient States and Societies in Korea: 57-76. Seoul: Ilchogak Press.

CHŎN, YŎNG-NAE

1994 The genealogy and dating of the bronze culture in Korea: Focusing on the multi-knobbed mirrors, in Chŏnbuk-to yujok chosa pogo (sang): 241-325. Seoul: Sŏgyŏng-Munhwasa Press.

CHŎNG, IN-SŎNG

1996 The nature of ding vessels in the Korean peninsula. Komunhwa 48:115-152.

CHŎNG, SANG-SŎK

2001 The Eastern Zhou swords and the development of the slender dagger culture in Kŭm River. Han'guk kodaesa yŏn'gu 22:59-84.

CKPPW (CHOSŎN Kisul PALJŎNSA P'YŎNCH'An WiwŎnHOE)

1996 The History of Technology in Chosŏn. P'yŏngyang: Kwahak Paekkwa Sajŏn Chonghap Ch'ulp'ansa Press.

Cosmo, Di Nicola

1994 Ancient Inner Asian Nomads: Their economic basis and its significance in Chinese history. The Journal of Asian Studies 53(4) : 1092-1126.

HedeAger, LotTe

1988 The evolution of Germanic society 1-400 A.D., in First Millennium Papers: Western Europe in the First Millennium A.D.: 129-144, ed. R.F.J. Jones. Oxford: B.A.R.

HMY (Honam MunhwajaE-Yŏn'GUWŎN)

2009 Wanju Kal-tong yujök II. Seoul: Sejong C\&C.

HODDER, IAN

1982 Toward a contextual approach to Prehistoric exchange, in Contexts for Prehistoric Exchange: 3-8, ed. Jonathon E. Ericson and Timothy K. Earle. New York: Academic Press.

Kim, Kwang-SU

1994 A study of official titles in Old Chosŏn. Yǒksa kyoyuk 56:1-20.

Kim, Kyu-Ho Song, You-na Kim, and Na-Young Kim

2005 An archaeological examination of glass beads in the Wanju Kal-tong site, in Wanju Kal-tong yujok II: 199-206. Seoul: Printed by Sejong C\&C.

KuKSA, P'YŎNCH'AN WiWŏNHOE

1989 Yǒkchu Chungguk chŏngsa Chosŏn chon 1:51-94. 
LAmberg-Karlovsky, C. C.

1972 Trade mechanisms in Indus-Mesopotamian interrelations. Journal of the American Oriental Society $92(2): 222-229$.

Li Huizhu AND Wang Qing

2002 Exchange between Shandong peninsula and Korea in late Bronze Age to early Iron Age. Paeksan hakpo $64: 5-25$.

Mikami, Tsugio

1966 A study of trade in ancient times. Kodaishi kōza-Kodai ni okeru kōeki to bunka kōryū 古代史 講座一古代におけみ交易と文化交流 13. Kyoto 東京: Kaksesha 學生社.

NAM, IL-YONG

1996a The characteristics of ancient earthen walled sites in P'yŏngyang. Chosŏn kogo yŏn'gu 3:16-19.

1996 b Dating of ancient earthen walled sites in P'yŏngyang. Choson kogo yŏn'gu 1:24-26.

1999 The nature of ancient earthen walled sites in the Taedong River valley. Chosón kogo yŏn'gu $1: 25-27$.

No, T'AE-DON

1998 The political structure of Wiman Chosŏn: An examination of official titles. Sanun sahak $8: 187-208$.

PAK SUN-BAL

1993 A study of developmental processes of early iron culture. Kogo misul Saron 3:37-63.

2001 Transition of foreign trade in Mahan and the emergence of Paekche. Paekche yon'gu 33:123.

PARK, SUN-MI

2000 A study of Old Chosŏn's culture and the knife-shaped money in the eastern Liao River in the third to second century вс. Sónsa wa kodae 14:139-166.

2005 The relations between currency using groups and Old Chosonn in the Warring States period to early Han. Pukbangsa nonch'ong 7:177-217.

2007 A study of knife-shaped money in Manchuria and the Korean peninsula in Ko Chosŏn ŭi yŏksa rŭl ch'ajasŏ: 217-278. Seoul: Hagyŏn Munhwasa Press.

2008 The significance of coins from the Han period excavated in the Korean peninsula. Sornsa wa kodae $28: 255-291$.

2009 The Ancient Currencies in Old Chosŏn and Northeast Asia. Seoul: Hagyŏn Munhwasa Press.

POLANYi, KarL

1957 The economy as instituted process, in Trade and Market in the Early Empires: 243-269, ed. Karl Polanyi, Conrad M. Arensberg, and Harry W. Pearson. Glencoe, IL: The Free Press and The Falcon's Wing Press.

RENFrew, COLIN

1975 Trade as action at distance: Questions of integration and communication, in Ancient Civilization and Trade: 3-59, ed. Jeremy A. Sabloff and C. C. Lamberg-Karlovsky. Albuquerque: University of New Mexico Press.

SCHEIDEL, WALTER

2008 The monetary systems of the Han and Roman empires, in Princeton Stanford Working Papers, Version 2.0. Princeton, NJ.

SKKY (Sahoe Kwahagwŏn KogOhak YŏN'guso)

1983 The archaeological report of tombs in the Nangnang district. Kogohak Charyojip 6:3-164. P'yŏngyang: Sahoe kwahak ch'ulp'ansa Press.

Sŏ YŏNG-SU

1988 The location and the boundary of Old Chosŏn. Han'guksa simin kangjwa 2:40-50.

SON RYANG-GU

1990 A study of the knife-shaped money discovered in the eastern Liao River and North Korea. Kogo minsok nonmunjip 12:28-47.

STEIN, J. GIL

1999 Rethinking World-Systems. Tucson: The University of Arizona Press.

TAMura, KōICHI 田村晃一

1994 The archaeology of the Lelang commandery: An examination of knife-shaped money in the north part of Ch’óngch’ŏn River, in Toasea Sekaisi no Denkai 東アジア世界史の展開, Tokyo 東京: Kyukoshoyin 波古書院. 
WANG, PEIXIN

2008 The nature of Lelang culture and its relations with the Central Plains of China. Unpublished paper presented at Taho-ri yujŏk palgul sŏnggwa wa kwaje kukche simp'ojiŏm (symposium) at the National Museum of Korea in Seoul, November 28-29, 2008.

YAMBERT, KARL

1981 Alien traders and ruling elites: The overseas Chinese in Southeast Asia and the Indians in East Africa. Ethnic Groups 3:173-198.

YI, CH'ŎNG-GYU

2002 Archaeological study of interaction between Korea and China during the 1st millennium BC. Han'guk kodaesa yon'gu 32:95-129.

Yi, Hyun-Hye

1997 Three Han. History of Korea $4: 262-263$.

YI, IN-SUK

1993 The ancient glass products in Korea from the trade of the East and the West. Han'gukhak yŏn'gu $5: 443-466$.

YI, KŎN-MU

1994 The nature of the Korean style bronze dagger culture: The background of its establishment, Tong Asia ŭi ch'ongdonggi munhwa, Munhwajae Yŏn'guso kukche haksul taehoe palp'yo nonmunjip 3:161-169.

YI, NAM-GYU

2005 Developing process of the iron culture in the proto-Koguryŏ period, in Koguryo ŭi kukka hyŏngsŏng: 15-56. Seoul: Koguryŏ Yŏn'gu Chaedan Press.

YI, SŎNG-JU

2000 The specialization and the high-firing technique in Ceramic production: The transformation of ceramic production systems in the Proto-Three kingdoms Period. Han'guk kogo hakpo $42: 57-106$.

ZHANG, BOQUAN

2004 A discourse of the knife-shaped money. Beifang wenu 4:48-52.

ZHANG, HONG

2003 A Study of Merchants Commercial Capital in the Warring States to Qin and Han. Beijing: Qilu Shushe Press.

\begin{abstract}
This article employs the theory of buffer zone trade to understand archaeological data related to trade in Wiman Chosŏn (195-108 B.C.), one of the earliest states in Korean history. Buffer zone trade is performed by an entity (B) placed between a fully developed state with a centralized government $(\mathrm{C})$, and an underdeveloped polity in a periphery (P). B creates a route to convey C's advanced products, and exports imported goods from $\mathrm{C}$ as well as its own products to neighboring polities in the periphery, while controlling the flow of luxury materials. Significantly, in this process B moderates the impact of more powerful and regionally dominant civilizations on the polities in the periphery, therefore preventing these peripheral polities from losing their indigenous cultures entirely or experiencing structural collapse. Furthermore, B exercises authority over the polities in the periphery, controlling the flow of advanced materials. Wiman Choson imported Han's monetary currency, iron products, weapons, farming tools, high-fired pottery, horse trappings, bronze mirrors, and bronze vessels, while exporting a few simple iron tools like hand knives, bronze mirrors, slender daggers, and fine-lined mirrors to Chin. Interestingly, the discrepancy of both the quality and quantity of the imported Han products takes place in the Korean Peninsula. Additionally, there was no influx of Han currencies and iron weaponry in the southern Korean Peninsula before the second century в.C. I believe that this phenomenon represents a result of trade conducted by Wiman Chosŏn and that Wiman Chosŏn functioned in this way as a semi-core. KeYwords: Korea, Buffer Zone Trade theory, Wiman Chosŏn, Han, Chin, currency, metals, World Systems, political economy.
\end{abstract}

